\title{
Analysis of the latitudinal variability of tropospheric ozone in the Arctic using the large number of aircraft and ozonesonde observations in early summer 2008
}

\author{
Gerard Ancellet $^{1}$, Nikos Daskalakis ${ }^{1}$, Jean Christophe Raut ${ }^{1}$, David Tarasick ${ }^{3}$, Jonathan Hair ${ }^{2}$, Boris Quennehen ${ }^{1}$, \\ François Ravetta $^{1}$, Hans Schlager ${ }^{4}$, Andrew J. Weinheimer ${ }^{5}$, Anne M. Thompson ${ }^{6}$, Bryan Johnson ${ }^{7}$, \\ Jennie L. Thomas ${ }^{1}$, and Katharine S. Law ${ }^{1}$ \\ ${ }^{1}$ LATMOS/IPSL, UPMC Univ. Paris 06 Sorbonne Universités, UVSQ, CNRS, Paris, France \\ ${ }^{2}$ NASA Langley Reasearch Center, Hampton, VA, USA \\ ${ }^{3}$ Environment and Climate Change Canada, Downsview, ON, Canada \\ ${ }^{4}$ Institut für Physik der Atmosphäre, DLR, Oberpfaffenhofen, Germany \\ ${ }^{5} \mathrm{NCAR}$, Boulder, CO, USA \\ ${ }^{6} \mathrm{NASA} / \mathrm{GSFC}$, Greenbelt, MD, USA \\ ${ }^{7}$ NOAA/Earth System Research Laboratory (ESRL), Boulder, CO, USA
}

Correspondence to: Gerard Ancellet (gerard.ancellet@latmos.ipsl.fr)

Received: 18 May 2016 - Published in Atmos. Chem. Phys. Discuss.: 20 May 2016

Revised: 26 September 2016 - Accepted: 11 October 2016 - Published: 28 October 2016

\begin{abstract}
During the 2008 International Polar Year, the POLARCAT (Polar Study using Aircraft, Remote Sensing, Surface Measurements, and Models of Climate Chemistry, Aerosols, and Transport) campaign, conducted in summer over Greenland and Canada, produced a large number of measurements from three aircraft and seven ozonesonde stations. Here we present an observation-integrated analysis based on three different types of $\mathrm{O}_{3}$ measurements: airborne lidar, airborne UV absorption or chemiluminescence measurement, and intensified electrochemical concentration cell (ECC) ozonesonde profiles. Discussion of the latitudinal and vertical variability of tropospheric ozone north of $55^{\circ} \mathrm{N}$ during this period is performed with the aid of a regional model (WFR-Chem). The model is able to reproduce the $\mathrm{O}_{3}$ latitudinal and vertical variability but with a negative $\mathrm{O}_{3}$ bias of 6-15 ppbv in the free troposphere above $4 \mathrm{~km}$, especially over Canada.

For Canada, large average $\mathrm{CO}$ concentrations in the free troposphere above $4 \mathrm{~km}$ (>130 ppbv) and the weak correlation $(<30 \%)$ of $\mathrm{O}_{3}$ and $\mathrm{PV}$ suggest that stratospheretroposphere exchange (STE) is not the major contributor to average tropospheric ozone at latitudes less than $70^{\circ} \mathrm{N}$, due to the fact that local biomass burning (BB) emissions were
\end{abstract}

significant during the 2008 summer period. Conversely, significant STE is found over Greenland according to the better $\mathrm{O}_{3}$ vs. PV correlation ( $>40 \%$ ) and the higher values of the 75th PV percentile. It is related to the persistence of cyclonic activity during the summer over Baffin Bay.

Using differences between average concentration above Northern and Southern Canada, a weak negative latitudinal summer ozone gradient of -6 to $-8 \mathrm{ppbv}$ is found in the mid-troposphere between 4 and $8 \mathrm{~km}$. This is attributed to an efficient $\mathrm{O}_{3}$ photochemical production from $\mathrm{BB}$ emissions at latitudes less than $65^{\circ} \mathrm{N}$, while the STE contribution is more homogeneous in the latitude range $55-70^{\circ} \mathrm{N}$. A positive ozone latitudinal gradient of $12 \mathrm{ppbv}$ is observed in the same altitude range over Greenland not because of an increasing latitudinal influence of STE, but because of different long-range transport from multiple mid-latitude sources (North America, Europe, and even Asia for latitudes higher than $77^{\circ} \mathrm{N}$ ).

For the Arctic latitudes $\left(>80^{\circ} \mathrm{N}\right)$, free tropospheric $\mathrm{O}_{3}$ concentrations during summer 2008 are related to a mixture of Asian pollution and stratospheric $\mathrm{O}_{3}$ transport across the tropopause. 


\section{Introduction}

Ozone concentrations are still increasing in many locations in the Northern Hemisphere mostly due to an increase in Asian precursor emissions (Lin et al., 2015; Cooper et al., 2010). Since tropospheric ozone is an effective greenhouse gas with a relatively long lifetime, its main impact on climate and air quality is within mid-latitude regions. Several studies have shown that ozone also makes an important contribution to the Arctic surface temperature increases due to direct local warming in the Arctic as well as heat transport following warming due to ozone at mid-latitudes (Shindell, 2007; Shindell et al., 2009; AMAP, 2015). The Arctic ozone budget still requires better quantification and is complicated by the interplay between the long-range transport, including the downward transport of stratospheric ozone (Hess and Zbinden, 2013; Walker et al., 2012), removal of boundary layer $\mathrm{O}_{3}$ due to halogen chemistry, especially in springtime (Simpson et al., 2007; Abbatt et al., 2012), and photochemical production due to local sources, such as boreal forest fires (Stohl et al., 2007; Thomas et al., 2013), $\mathrm{NO}_{\mathrm{x}}$ enhancement from snowpack emissions (Honrath et al., 1999; Legrand et al., 2009), local summertime production from peroxyacetyl nitrate (PAN) decomposition (Walker et al., 2012), or ship emissions (Granier et al., 2006). The $\mathrm{O}_{3}$ distribution over North America for the spring period at high latitude has been discussed using the Tropospheric Ozone Production about the Spring Equinox (TOPSE) and Arctic Research of the Composition of the Troposphere from Aircraft and Satellites (ARCTAS) data set in several publications (Browell et al., 2003; Wang et al., 2003; Olson et al., 2012; Koo et al., 2012) showing (i) frequent occurrence of ozone depletion events (ODE) in the planetary boundary layer (PBL), (ii) a net $\mathrm{O}_{3}$ photochemical production rate equal to zero throughout most of the troposphere, and (iii) a latitudinal increase of tropospheric $\mathrm{O}_{3}$ concentrations due to transport from mid-latitudes and stratosphere-troposphere exchange (STE).

For the summer period ozone photochemical production is expected according to the numerous studies conducted at mid-latitudes (Crutzen et al., 1999; Parrish et al., 2012), but little attention has been given to the high latitude distribution during this season. During the ARCTAS-B (Jacob et al., 2010) and POLARCAT (Polar Study using Aircraft, Remote Sensing, Surface Measurements, and Models of Climate Chemistry, Aerosols, and Transport) campaigns (Law et al., 2014), many ozone measurements were carried out over Canada and Greenland from 15 June to 15 July 2008 via aircraft and regular ozone soundings. This allows a detailed analysis of the ozone regional distribution at high latitudes between 55 and $90^{\circ} \mathrm{N}$ and a discussion about the relevant ozone sources driving the summer ozone values. So far, knowledge of the relative influence of the main ozone summer sources has been mainly derived from modeling studies, e.g., summer simulations of global model simulation of the ozone source attribution (Wespes et al., 2012; Walker et al., 2012; Monks et al., 2015), or regional modeling of biomass burning case studies for North American fires (Thomas et al., 2013) or Asian fires (Dupont et al., 2012).

In order to interpret the measurements, we use a hemispheric simulation performed using the regional chemical transport model, WRF-Chem (Grell et al., 2005; Fast et al., 2006). WRF-Chem simultaneously produces a meteorological forecast, including the dynamics of the upper troposphere and lower stratosphere (UTLS) region, and online chemistry to predict ozone (and other trace gas and aerosol) concentrations. Here, we use the WRF-Chem model to investigate dynamics that determine ozone concentrations as a function of latitude, including STE processes, which can bring highozone air from the stratosphere into the upper troposphere in the Arctic. In addition, we use the model to compare directly predicted and measured ozone in summer 2008 and use CO as a tracer to separate air influenced by surface emissions and subsequent ozone formation via photochemistry from air influenced by stratosphere-troposphere mixing processes.

The objectives of this paper are thus twofold: (i) to establish the summer tropospheric ozone latitudinal variability over Greenland and Canada based on the large number of ozone measurements available in the free troposphere during June-July 2008, and (ii) to explore the role of photochemistry and STE in the observed high latitude ozone distribution by extracting the potential vorticity (PV) and $\mathrm{CO}$ distribution from a 2 month WRF-Chem regional model simulation. The WRF-Chem simulation also provides the modeled ozone distribution to verify the coherence between the modeled PV and CO with the observed ozone distributions. The ozone data set and the WRF-Chem simulation are described in Sects. 2 and 3, respectively. The model vs. measurement ozone comparison is discussed in Sect. 4, while the latitudinal distributions of ozone, $\mathrm{CO}$, and $\mathrm{PV}$ are presented in Sect. 5 .

\section{Summer 2008 ozone data set}

We use three different ozone measuring instruments to build the data set considered in this work: airborne lidar, in situ aircraft ozone analyzer, and electrochemical concentration cell (ECC) ozonesonde. Two airborne ozone differential absorption lidars (DIAL) are considered: the NASA-DC-8 instrument and the ALTO lidar on the French ATR-42. In situ ozone analyzers have been installed onboard three different aircraft: the NASA DC-8, the DLR Falcon-20, and the French ATR-42. We also considered seven ground-based stations that participated in the ARC-IONS campaign (Tarasick et al., 2010) over Canada (latitudes $>50^{\circ} \mathrm{N}$ in the longitude range between -70 and $-160^{\circ} \mathrm{W}$ ) and over Greenland (latitudes $>55^{\circ} \mathrm{N}$ in the longitude range between -60 and $-20^{\circ} \mathrm{W}$ ). The times and positions of the June-July 2008 measurements included in our study are given in Table 1 for 
Table 1. Characteristics of the ensemble of ozone measurements made with airborne instruments during summer 2008.

\begin{tabular}{lrrrrr}
\hline Instrument & $\begin{array}{r}\text { Number } \\
\text { of flights }\end{array}$ & $\begin{array}{r}\text { Latitude } \\
\text { range }\end{array}$ & $\begin{array}{r}\text { Longitude } \\
\text { range }\end{array}$ & $\begin{array}{r}\text { Altitude } \\
\text { range }\end{array}$ & $\begin{array}{r}\text { Time } \\
\text { period }\end{array}$ \\
\hline ATR-42 in situ & 12 & $59-71^{\circ} \mathrm{N}$ & -60 to $-20^{\circ} \mathrm{W}$ & $0-7 \mathrm{~km}$ & 30 Jun-14 Jul \\
ATR-42 lidar & 12 & $59-71^{\circ} \mathrm{N}$ & -60 to $-20^{\circ} \mathrm{W}$ & $2-12 \mathrm{~km}$ & 30 Jun-14 Jul \\
DC-8 in situ & 11 & $45-88^{\circ} \mathrm{N}$ & -132 to $-38^{\circ} \mathrm{W}$ & $0-12 \mathrm{~km}$ & 26 Jun-13 Jul \\
DC-8 lidar & 11 & $45-88^{\circ} \mathrm{N}$ & -132 to $-38^{\circ} \mathrm{W}$ & $0-15 \mathrm{~km}$ & 26 Jun-10 Jul \\
Falcon-20 in situ & 18 & $57-79^{\circ} \mathrm{N}$ & -65 to $-20^{\circ} \mathrm{W}$ & $0-11 \mathrm{~km}$ & 30 Jun-18 Jul \\
\hline
\end{tabular}

Table 2. Characteristics of the ECC sounding stations used during summer 2008.

\begin{tabular}{lrrrrr}
\hline Station & $\begin{array}{r}\text { Number } \\
\text { of ECC }\end{array}$ & Latitude & Longitude & $\begin{array}{r}\text { Altitude } \\
\text { range }\end{array}$ & $\begin{array}{r}\text { Time } \\
\text { period }\end{array}$ \\
\hline Summit & 22 & $72.6^{\circ} \mathrm{N}$ & $-38.5^{\circ} \mathrm{W}$ & $3.2-15 \mathrm{~km}$ & 6 Jun-22 Jul \\
Alert & 8 & $82.5^{\circ} \mathrm{N}$ & $-62.3^{\circ} \mathrm{W}$ & $0-15 \mathrm{~km}$ & 4 Jun-24 Jul \\
Resolute & 8 & $74.7^{\circ} \mathrm{N}$ & $-95^{\circ} \mathrm{W}$ & $0-15 \mathrm{~km}$ & 4 Jun-30 Jul \\
Churchill & 16 & $58.7^{\circ} \mathrm{N}$ & $-94^{\circ} \mathrm{W}$ & $0-15 \mathrm{~km}$ & 4 Jun-30 Jul \\
Yellowknife & 19 & $62.5^{\circ} \mathrm{N}$ & $-114.5^{\circ} \mathrm{W}$ & $0-15 \mathrm{~km}$ & 23 Jun-12 Jul \\
Whitehorse & 15 & $60.7^{\circ} \mathrm{N}$ & $-135.1^{\circ} \mathrm{W}$ & $0-15 \mathrm{~km}$ & 27 Jun-12 Jul \\
Stonyplain & 16 & $53.55^{\circ} \mathrm{N}$ & $-114.11^{\circ} \mathrm{W}$ & $0-15 \mathrm{~km}$ & 26 Jun-12 Jul \\
\hline
\end{tabular}

Measurements over Canada

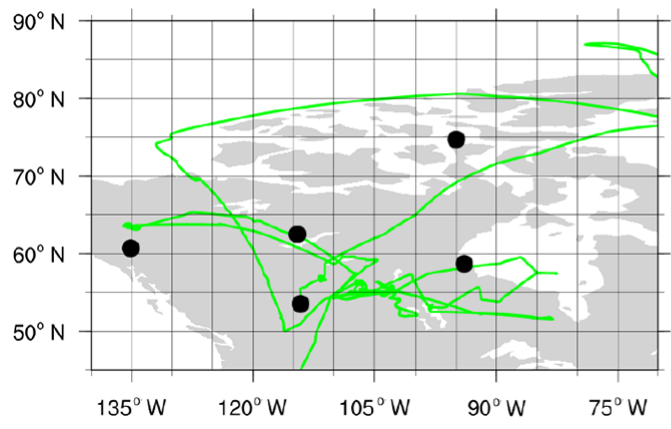

Measurements over Greenland

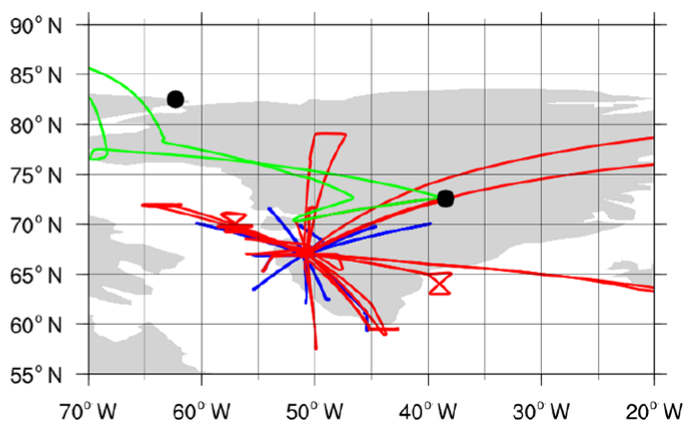

Figure 1. Horizontal distribution of the DC-8 (green), ATR-42 (blue), DLR Falcon-20 (red) flights and ECC sounding locations (black dot) over the selected Canada (left panel) and Greenland regions (right panel).

the aircraft observations and in Table 2 for the ozonesondes. The aircraft flight paths over Canada and Greenland are shown in Fig. 1 and the measurements are always performed during daytime.

The German DLR Falcon-20 was based in Greenland and used an UV absorption instrument (Thermo Environment Instruments,Inc.; TEI49C) to measure $\mathrm{O}_{3}$ with an uncertainty of $\pm 2 \mathrm{ppbv}$ ( $\pm 5 \%$ of the signal) (Schlager et al., 1997; Roiger et al., 2011). The ATR-42 aircraft was also based in Greenland and the ozone measurements were made using a similar instrument (TEI49-103) calibrated against a NIST (National Institute of Standards and Technology)-referenced $\mathrm{O}_{3}$ calibrator, Model 49PS, at zero, 250, 500, and $750 \mathrm{ppbv}$ (Marenco et al., 1998). A 4 ppbv negative bias related to $\mathrm{O}_{3}$ loss in the ATR-42 air inlet (e.g., $10 \%$ for $40 \mathrm{ppbv}$ and $5 \%$ for $80 \mathrm{ppbv}$ ) has been corrected in this study. On 14 July
2008, the comparison of the ATR-42 and the DLR Falcon20 ozone data at two altitude levels over Greenland (near $67^{\circ} \mathrm{N}$ ) shows an uncertainty better than 2 ppbv (Fig. 2). The NASA DC-8 (Weinheimer et al., 1994) $\mathrm{O}_{3}$ measurements were made with a chemiluminescence technique, with the instrument calibrated by additions of $\mathrm{O}_{3}$ determined by $\mathrm{UV}$ optical absorption at $254 \mathrm{~nm}$. Uncertainties in the $\mathrm{DC}-8 \mathrm{O}_{3}$ data are typically \pm 2 ppbv ( $\pm 5 \%$ of the signal). The NASA DC- 8 flew mainly over Canadian forest fire regions in summer ( $\mathrm{Ja}$ cob et al., 2010). The comparison between the NASA DC8 and the DLR Falcon- $20 \mathrm{O}_{3}$ data during an aircraft intercomparison flight on 9 July over northern Greenland shows very good precision, but a 4 ppbv positive difference (Fig. 2). None of the Falcon-20 and NASA DC-8 data were corrected.

The ALTO lidar was mounted in a zenith viewing mode making ozone vertical profiles above the aircraft, thus limit- 

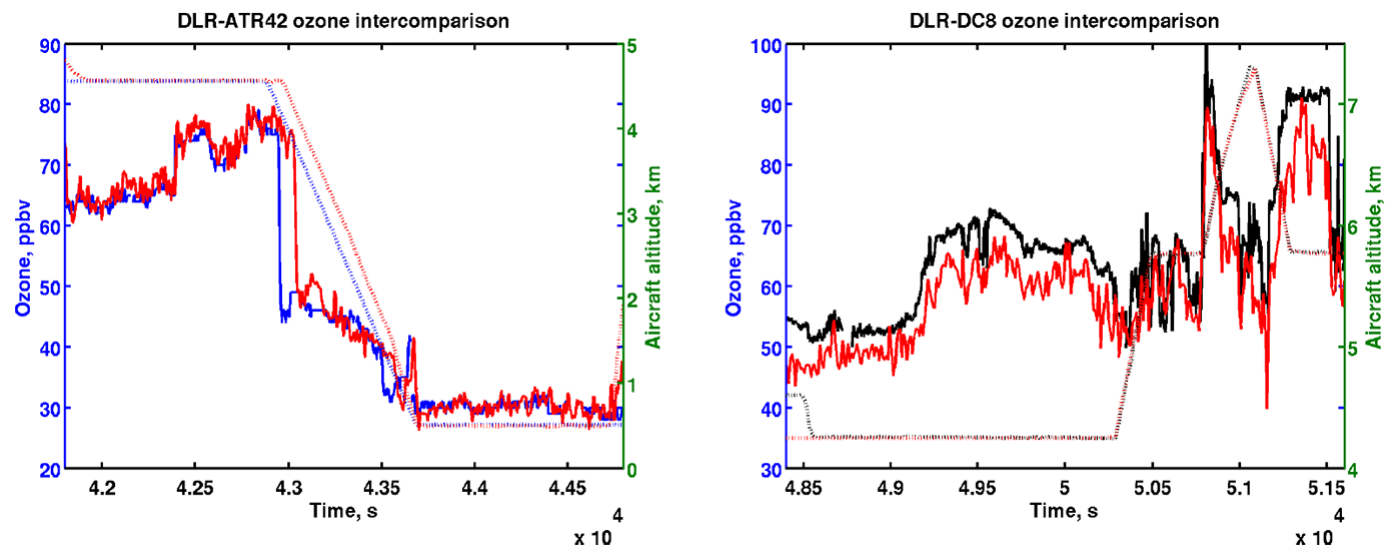

Figure 2. Intercomparison of $\mathrm{O}_{3}$ measurements in ppbv (solid line and left vertical scale) during two wing tip-to-wing tip flights over Greenland between the ATR-42 (blue) and the DLR Falcon-20 (red) on 14 July (left panel) and between the NASA-DC-8 (black) and the DLR Falcon-20 (red) on 9 July (right panel). The aircraft altitude changes are in km (dotted line and right vertical scale).

ing the number of $\mathrm{O}_{3}$ data available at altitudes below $3 \mathrm{~km}$. The lidar measurement altitude range is of the order of $6 \mathrm{~km}$ above the aircraft flight level with a $300 \mathrm{~m}$ vertical resolution and a $10 \mathrm{~km}$ horizontal resolution (i.e., a 2 min integration time). The system is fully described in Ancellet and Ravetta (1998), and the instrument performances for different examples of daytime airborne measurements are discussed in Ancellet and Ravetta (2003) (urban pollution in the boundary layer, ozone in the UTLS, and long-range transport in the free troposphere). Several comparisons with in situ measurements (ECC ozonesonde and airborne UV photometer) show no specific biases in clear air measurements. Measurements taken near clouds or thick aerosol layers are not included here since corrections of systematic errors related to aerosol interference become very large (Papayannis et al., 1990). These represent $20 \%$ of the lidar profiles recorded during the campaign.

The NASA-DC-8 Ozone DIAL system and configuration implemented during the campaign is described by Richter et al. (1997). The instrument provides simultaneous zenith and nadir profiles to cover the troposphere and lower stratosphere. The $\mathrm{O}_{3}$ measurement resolution is $300 \mathrm{~m}$ in the vertical and approximately $70 \mathrm{~km}(3 \mathrm{~min})$ in the horizontal for daytime measurements. On all field experiments, the airborne DIAL $\mathrm{O}_{3}$ measurements are compared with in situ $\mathrm{O}_{3}$ measurements made on the DC- 8 during ascents, descents, and spirals, while comparisons to ozonesondes during coincident overflights were also conducted. In the troposphere, the DIAL $\mathrm{O}_{3}$ measurements have been shown to be accurate to better than $10 \%$ or $2 \mathrm{ppb}$, whichever is larger (Browell et al., 1983, 1985). More recently, the precision of the DIAL $\mathrm{O}_{3}$ measurements during the high-latitude SAGE-III Ozone Loss and Validation Experiment in 2003 (SOLVE II) was found to be better than $5 \%$ from near the surface to about $24 \mathrm{~km}$ and the accuracy was found to be better than $10 \%$ in comparison with the Ny-Ålesund lidar, ozonesondes, and in situ DC-8 measurements (Lait et al., 2004). DIAL and Microwave Limb Sounder (MLS) $\mathrm{O}_{3}$ measurements from the Polar Aura Validation Experiment (PAVE) in 2005 were found to agree within $7 \%$ across the $12-24 \mathrm{~km}$ altitude range (Froidevaux et al., 2008). Comparisons between DIAL and MLS were also examined in the upper troposphere and lower stratosphere (215-100 hPa region) from data obtained during the International Intercontinental Chemical Transport Experiment (INTEX-B) field experiment, and these results show good agreement in the lower stratosphere, with decreasing performance of the MLS measurements into the troposphere (Livesey et al., 2008).

The ozonesonde monitoring was intensified in 2008 over North America in the framework of the ARCIONS initiative and the characteristics of the ozone measurements are fully described in Tarasick et al. (2010). Nearly daily soundings were made during the aircraft flight period at four stations over Canada between 53 and $63^{\circ} \mathrm{N}$, and at Summit, Greenland, while weekly soundings were made at the high latitude stations Alert and Resolute.

The latitudinal cross sections of the ozone data set selected in this study are shown in Fig. 3 considering two domains to produce a bidimensional latitude-altitude plot over Canada $\left(-160\right.$ to $\left.-70^{\circ} \mathrm{W}\right)$ and Greenland $\left(-70\right.$ to $\left.-20^{\circ} \mathrm{W}\right)$. The horizontal distributions of the data set used for producing the latitude-altitude plots are shown in Fig. 1. For latitudes higher than $80^{\circ} \mathrm{N}$, the data comes from a limited number of observations: eight sondes from Alert and three DC-8 flights from 8 to 10 July. The locations of the ozonesonde stations are shown as red vertical bars in the latitudinal cross sections. In the troposphere at altitudes less than $8 \mathrm{~km}$ over Canada, lidar, in situ, and ozonesonde measurements contribute 67 , 20 , and $13 \%$ of the ozone data set, respectively, while they correspond to 26,69 , and $5 \%$, respectively, over Greenland (see the number of observations using each technique in Table 3). The aircraft data (lidar and in situ) therefore strongly 

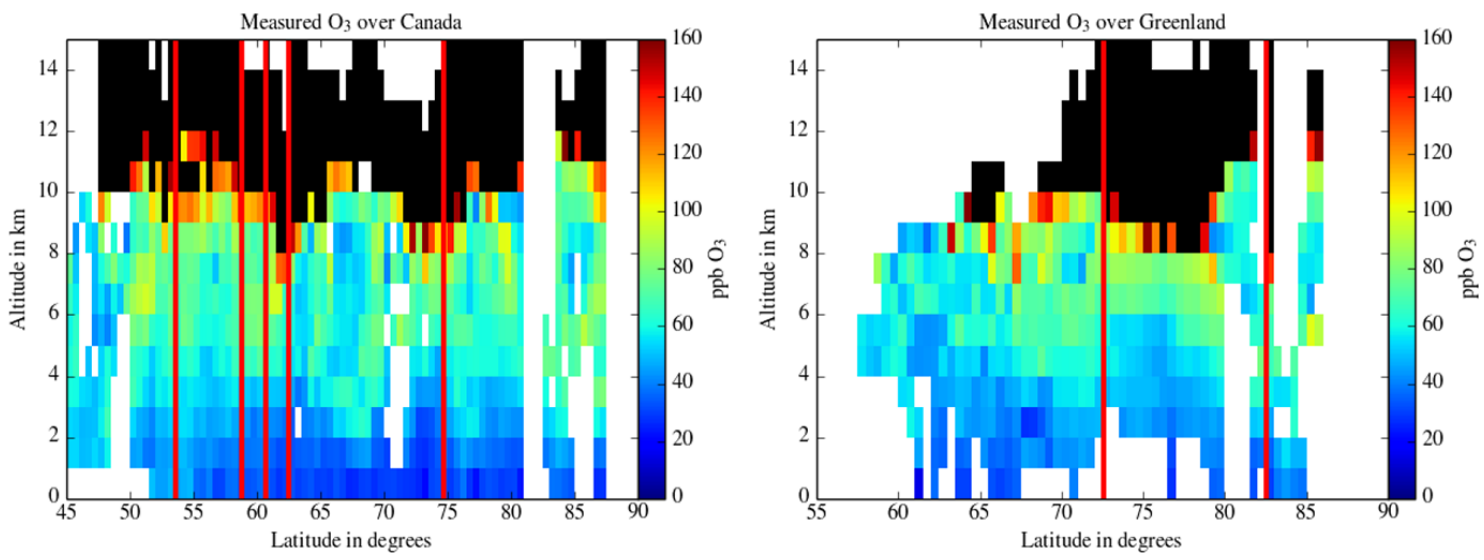

Figure 3. Latitudinal cross section of the measured ozone mixing ratio in ppbv over Canada (left panel) and over Greenland (right panel). The red bars show the location of ozonesonde stations. Black regions with $\mathrm{O}_{3}>160 \mathrm{ppbv}$ correspond to the stratosphere.

Table 3. Mean, median, and standard deviation of the observed ozone mixing ratio in the different boxes shown in Figs. 7 and 9 , except for the two boxes at latitudes $>80^{\circ} \mathrm{N}$, which have been merged in the last row of the table.

\begin{tabular}{lrrrrrrrrr}
\hline $\begin{array}{l}\text { Zone } \\
\mathrm{N}^{\circ}\end{array}$ & $\begin{array}{r}\text { Latitude } \\
\text { range }\end{array}$ & $\begin{array}{r}\text { Longitude } \\
\text { range }\end{array}$ & $\begin{array}{r}\text { Altitude } \\
\mathrm{km}\end{array}$ & $\begin{array}{r}\mathrm{O}_{3} \text { mean } \\
\mathrm{ppbv}\end{array}$ & $\begin{array}{r}\mathrm{O}_{3} \text { median } \\
\text { ppbv }\end{array}$ & $\begin{array}{r}\mathrm{O}_{3} \mathrm{SD} \\
\text { ppbv }\end{array}$ & $\begin{array}{r}\text { Number } \\
\text { lidar }\end{array}$ & $\begin{array}{r}\text { Number } \\
\text { in situ }\end{array}$ & $\begin{array}{r}\text { Number } \\
\mathrm{ECC}\end{array}$ \\
\hline 1 & $50-65^{\circ} \mathrm{N}$ & -132 to $-70^{\circ} \mathrm{W}$ & $0-4$ & 45.8 & 45.3 & 10.8 & 1046 & 422 & 243 \\
2 & $65-80^{\circ} \mathrm{N}$ & -132 to $-70^{\circ} \mathrm{W}$ & $0-4$ & 42.3 & 40.9 & 11.4 & 401 & 27 & 28 \\
3 & $50-63^{\circ} \mathrm{N}$ & -132 to $-70^{\circ} \mathrm{W}$ & $4-8$ & 69.4 & 68.0 & 18.8 & 1184 & 349 & 240 \\
4 & $63-75^{\circ} \mathrm{N}$ & -132 to $-70^{\circ} \mathrm{W}$ & $4-8$ & 63.4 & 62.0 & 16.5 & 360 & 123 & 28 \\
\hline 5 & $60-80^{\circ} \mathrm{N}$ & -70 to $-20^{\circ} \mathrm{W}$ & $0-4$ & 45.1 & 45.4 & 8.0 & 243 & 603 & 21 \\
6 & $57-65^{\circ} \mathrm{N}$ & -70 to $-20^{\circ} \mathrm{W}$ & $4-8$ & 57.4 & 56.1 & 13.8 & 22 & 203 & 0 \\
7 & $65-75^{\circ} \mathrm{N}$ & -70 to $-20^{\circ} \mathrm{W}$ & $4-8$ & 68.7 & 68.1 & 16.3 & 320 & 906 & 81 \\
\hline 8 & $80-87^{\circ} \mathrm{N}$ & -132 to $-20^{\circ} \mathrm{W}$ & $3-8$ & 69.8 & 67.6 & 14.8 & 166 & 48 & 35 \\
\hline
\end{tabular}

contribute to the high measurement density even though they correspond to a limited number of flying days, i.e., 18 days from 26 June to 18 July. In this work, ozone data are averaged hourly when they are in the same cell of a grid, with $0.5 \times 0.5^{\circ}$ and $1 \mathrm{~km}$ vertical resolution in order to avoid an oversampling of similar air masses. Only hourly averages are considered in Table 3.

For both regions similar ozone vertical distributions were observed: low $\mathrm{O}_{3}$ mixing ratio $\leq 40 \mathrm{ppbv}$ below $3 \mathrm{~km}$ and high $\mathrm{O}_{3}$ concentrations typical of the UTLS in the altitude range $8-11 \mathrm{~km}$ between 60 and $80^{\circ} \mathrm{N}$ (i.e., red and dark region with $\mathrm{O}_{3}$ mixing ratio $>150 \mathrm{ppbv}$ ). The average $\mathrm{O}_{3}$ mixing ratio in the altitude range $4-8 \mathrm{~km}$ is of the order of $65 \mathrm{ppbv}$ for both regions but the latitudinal $\mathrm{O}_{3}$ gradients are more visible over Greenland than over Canada. Two midtropospheric ozone branches are seen in the latitude band 6573 and $78-85^{\circ} \mathrm{N}$ over Greenland, the former being tilted to the south at $70^{\circ} \mathrm{N}$ and the latter to the north at $80^{\circ} \mathrm{N}$.

\section{WRF-Chem model simulation}

\subsection{Model description}

For this study we use the regional Weather Research Forecasting model coupled with Chemistry (WRF-Chem) to study ozone during this period. WRF-Chem is a fully coupled, online meteorology and chemistry, and transport mesoscale model. It has been successfully used in Arcticfocused studies in the past (Thomas et al., 2013; Marelle et al., 2015) for both gas phase and aerosol analysis. Initial meteorological conditions and boundaries are from the $\mathrm{Na}$ tional Center for Environmental Prediction (NCEP) Global Forecast System (GFS) with nudging applied to temperature, wind, and humidity every $6 \mathrm{~h}$. The simulation uses the Noah Land Surface model scheme with four soil layers, the YSU (Yonsei University) planetary boundary layer (PBL) scheme (Hong et al., 2006), coupled with the MM5 similarity surface layer physics, the Morrison 2-moment (Morrison et al., 2009) microphysics scheme, and the Grell-3D ensemble (Grell and Dévényi, 2002) convective implicit parametrization. The radiation schemes are the Goddard (Chou and Suarez, 1994) 
and rapid radiative transfer model (Mlawer et al., 1997) for shortwave and long wave radiation, respectively. Chemical boundary conditions were taken from the Model For Ozone and Related chemical Tracers, version 4 (Emmons et al., 2010). For gas phase chemical calculations the CBM-Z (Zaveri and Peters, 1999) chemical scheme is used and aerosols were calculated using the Model for Simulating Aerosol Interactions and Chemistry (Zaveri et al., 2008). The model was run from 15 March to 1 August 2008 using a polar stereographic grid $(100 \times 100 \mathrm{~km}$ resolution $)$ over a domain that covers most of the Northern Hemisphere, from about $28^{\circ} \mathrm{N}$. Vertically, 50 hybrid layers up to $50 \mathrm{hPa}$ are used with approximately 10 levels in the first $2 \mathrm{~km}$. The corresponding vertical resolution ranges from $100 \mathrm{~m}$ in the PBL to $500 \mathrm{~m}$ in the free troposphere. Anthropogenic emissions with a $0.5^{\circ} \times 0.5^{\circ}$ spatial resolution were taken from the ECLIPSE (Evaluating the Climate and Air Quality Impacts of Short-Lived Pollutants) version 4.0 (Klimont et al., 2013). Wildfire emissions were taken from GFED 3.1 (van der Werf et al., 2010), while aircraft and shipping emissions were from the RCP 6.0 scenario (Lee et al., 2009 and Buhaug et al., 2009). Biogenic emissions were calculated online thanks to MEGAN (Model of Emissions of Gases and Aerosols from Nature) (Guenther et al., 2012).

Using observations from aircraft, surface stations, and satellites, atmospheric model simulations of $\mathrm{O}_{3}$ have been evaluated as part of POLMIP, including WRF-Chem (Monks et al., 2015; AMAP, 2015). The model was run using different emissions and gas/aerosol schemes than in the POLMIP simulations, but the POLMIP results are still a good basis to choose WRF-Chem. While all models have deficiencies in reproducing trace gas concentration in the Arctic, WRFChem performs better than many models in re-producing tropospheric $\mathrm{O}_{3}$ and $\mathrm{CO}$, which are used here. Given the advantages of also predicting stratosphere-troposphere exchange processes online for this study, WRF-Chem is a good model for interpreting these ozone climatologies constructed from measurements in summer 2008.

The WRF-Chem model does not explicitly calculate potential vorticity (PV). As a result, PV was calculated offline based on WRF meteorological fields: potential temperature, total mass density, geopotential height, and wind speed and direction. For each model grid cell, wind and temperature are interpolated from model vertical levels to the potential temperature in the center of the grid cell and the curl of the wind vector is calculated on the corresponding isentropic surfaces using the original model grid $(100 \mathrm{~km} \times 100 \mathrm{~km})$ and the full model vertical resolution, i.e., approximately $500 \mathrm{~m}$ in the free troposphere. Potential vorticity is expressed in potential vorticity units $(\mathrm{PVu})$ using the definition $1 \mathrm{PVu}=$ $10^{-6} \mathrm{Kkg}^{-1} \mathrm{~m}^{-2} \mathrm{~s}^{-1}$. The main uncertainty in the PV calculation is related to the representation of smaller scales $(50 \mathrm{~km})$ than the model resolution (e. g., narrow stratospheric streamers near the tropopause).

\subsection{Model results interpolations}

The measurements used in this study vary in temporal and spatial resolution (Sect. 2), where the model results are 3 hourly on a polar stereographic grid (described in Sect. 3). In order to avoid favoring data with the highest temporal resolution, the measured data were averaged to $1 \mathrm{~min}$ for all the in situ and lidar measurements. The ozonesondes are considered to be instantaneous at the time of the balloon release. A vertical resolution of $1 \mathrm{~km}$ is used for the lidars and ozonesondes. The measured data is then gridded to $0.5^{\circ} \times 0.5^{\circ}$. If more than one measurement is available in the same grid box from the same campaign and instrument within an interval of one hour, then these are considered to be the same measurement, and a mean value is calculated.

The model grid cell, which is the most representative for the measurement's location in space, is selected and a linear interpolation in time is done to calculate $1 \mathrm{~min}$ increments from the two modeled values separated by $3 \mathrm{~h}$ and surrounding the measurement time. In this way the two resulting data sets (modeled and measured) both have $1 \mathrm{~min}$ temporal resolution, and spatially only the vertical resolution is changed to set the altitude increment to $1 \mathrm{~km}$. The model results, including $\mathrm{PV}$, are also horizontally interpolated from $100 \mathrm{~km}$ resolution to match the new $0.5^{\circ} \times 0.5^{\circ}$ horizontal data resolution. Each model grid cell is split into 100 minigrid cells. Then each mini-grid cell is assigned to the appropriate $0.5^{\circ} \times 0.5^{\circ}$ final grid cell before calculating the new model values.

\section{Comparison of measured and modeled ozone}

The WRF-Chem ozone mixing ratios corresponding to the times and locations of the June-July observations have been used to produce latitudinal cross sections comparable to the results shown in Fig. 3. The modeled $\mathrm{O}_{3}$ latitudinal cross sections are shown for Canada and for Greenland in Fig. 4, while the corresponding relative differences between the model results and the measurements are shown in Fig. 5. The altitude and latitude ozone variability of the model is comparable to the observations over both regions. The vertical structure, i.e., the transition between the low ozone values below $3 \mathrm{~km}$ and the higher ozone concentration in the free troposphere, and the UTLS ozone variability, are well reproduced. The latitudinal gradient of the ozone concentration in the 4-8 km altitude range over Greenland is also visible in the simulation results where the two mid-tropospheric ozone branches are also visible at 70 and $80^{\circ} \mathrm{N}$. This structure is slightly shifted in the modeled cross section explaining both positive and relative differences in the free troposphere over Greenland (Fig. 5). The agreement is less good for the latitudinal gradient over Canada where the low ozone values $(<50 \mathrm{ppbv})$ seen in the model at $65^{\circ} \mathrm{N}$ in the mid-troposphere are not 

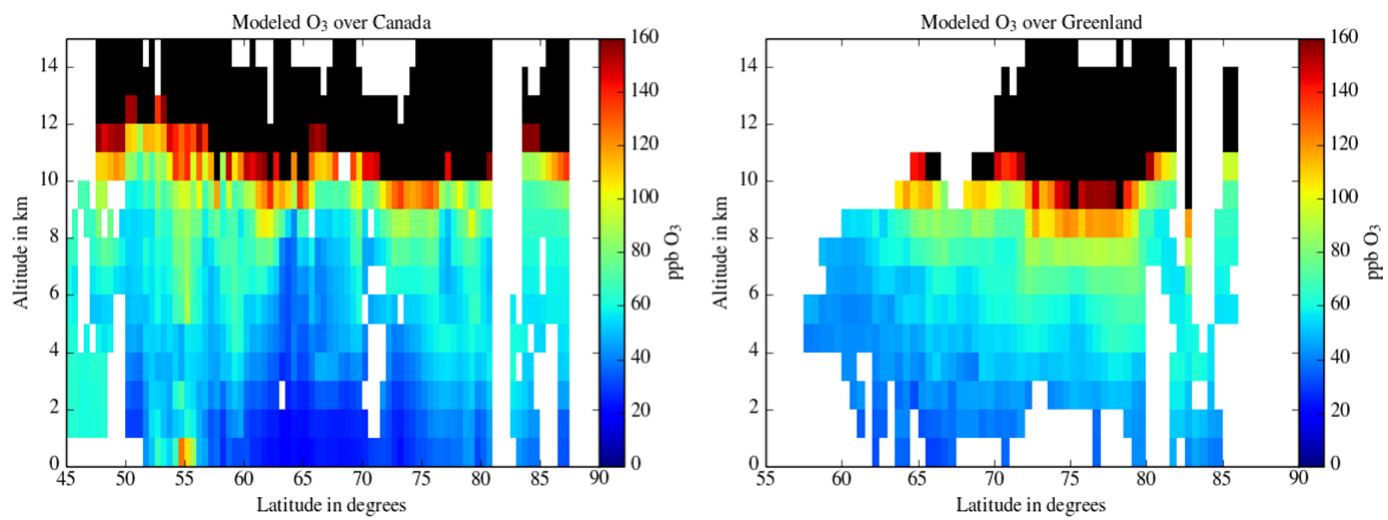

Figure 4. Same as Fig. 3 but for the WRF-Chem model ozone mixing ratio corresponding to the measurement characteristics summarized in Tables 1 and 2.
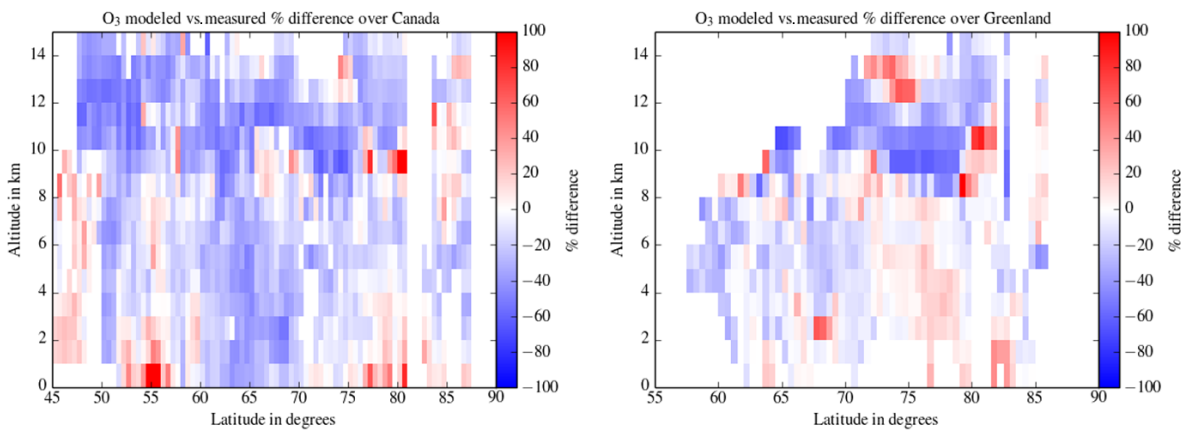

Figure 5. Same as Figs. 3 and 4 for the ozone mixing ratio relative differences between the WRF-Chem model and the measurements.

seen in the observations, although the signs of the latitudinal gradients seem correct.

To quantify the observation-model agreement the scatter plot of modeled vs. measured ozone is also presented in Fig. 6 using a PV color scale to distinguish the tropospheric and stratospheric contributions. The measured vs. modeled $\mathrm{O}_{3}$ correlation (red line in Fig. 6) is of the order of 0.9 in the altitude range $0-15 \mathrm{~km}$ over both regions because the occurrence of stratospheric ozone intrusions are very well reproduced by WRF-Chem. The correlation is however between 0.5 and 0.7 in the troposphere only using observations with $\mathrm{PV}$ values less than $1 \mathrm{PVu}$ (green line in Fig. 6). Considering that the ozone variability in the free troposphere is not very large $(<50 \mathrm{ppb})$, the spatial and temporal variability is still well reproduced by WRF-Chem even below the tropopause region. Even though the UTLS temporal variability is well reproduced by the model (Fig. 4), there is a significant underestimation of ozone by a factor 1.5 in the WRF-Chem simulation for the lowermost stratosphere (PV $>2 \mathrm{PVu}$ ) (Figs. 5 and 6). In the troposphere there is also a negative bias of the model data of the order of -6 to -15 ppbv with the largest differences over Canada (see Table 5). A fraction of this tropospheric underestimate by WRF-Chem is likely related to the $\mathrm{O}_{3}$ underestimate in the lowermost stratosphere, causing the stratospheric ozone source in the upper troposphere to be too small. The modeled $\mathrm{O}_{3}$ underestimate in the lower stratosphere likely originates from the $\mathrm{O}_{3}$ climatology used to initialize the model in the stratosphere. The other part of this 10-ppbv bias is due to an underestimate of the lightning $\mathrm{NO}_{x}$ contribution in the WRF-Chem simulation and/or an underestimate of the vertical transport of continental emissions to the mid- and upper troposphere. Wespes et al. (2012) have shown that the lightning $\mathrm{NO}_{x}$ source and vertical transport of continental emissions both contribute to $15 \%$ of the $\mathrm{O}_{3}$ concentration in the free troposphere at latitudes higher than $60^{\circ} \mathrm{N}$ in summer. Despite these flaws, the WRF-Chem simulations are still very valuable because the spatial $\mathrm{O}_{3}$ variability compares rather well with the observations. The PV and CO distribution available from the WRF-Chem simulations will therefore be used to examine the respective roles of photochemistry and STE in the observed ozone distribution in the following sections.

\section{Latitudinal ozone distribution at high latitudes}

In this section, we investigate the mean latitudinal and vertical ozone gradient in the troposphere using the POLARCAT observations. To quantify these gradients, the $\mathrm{O}_{3}$ cross sec- 


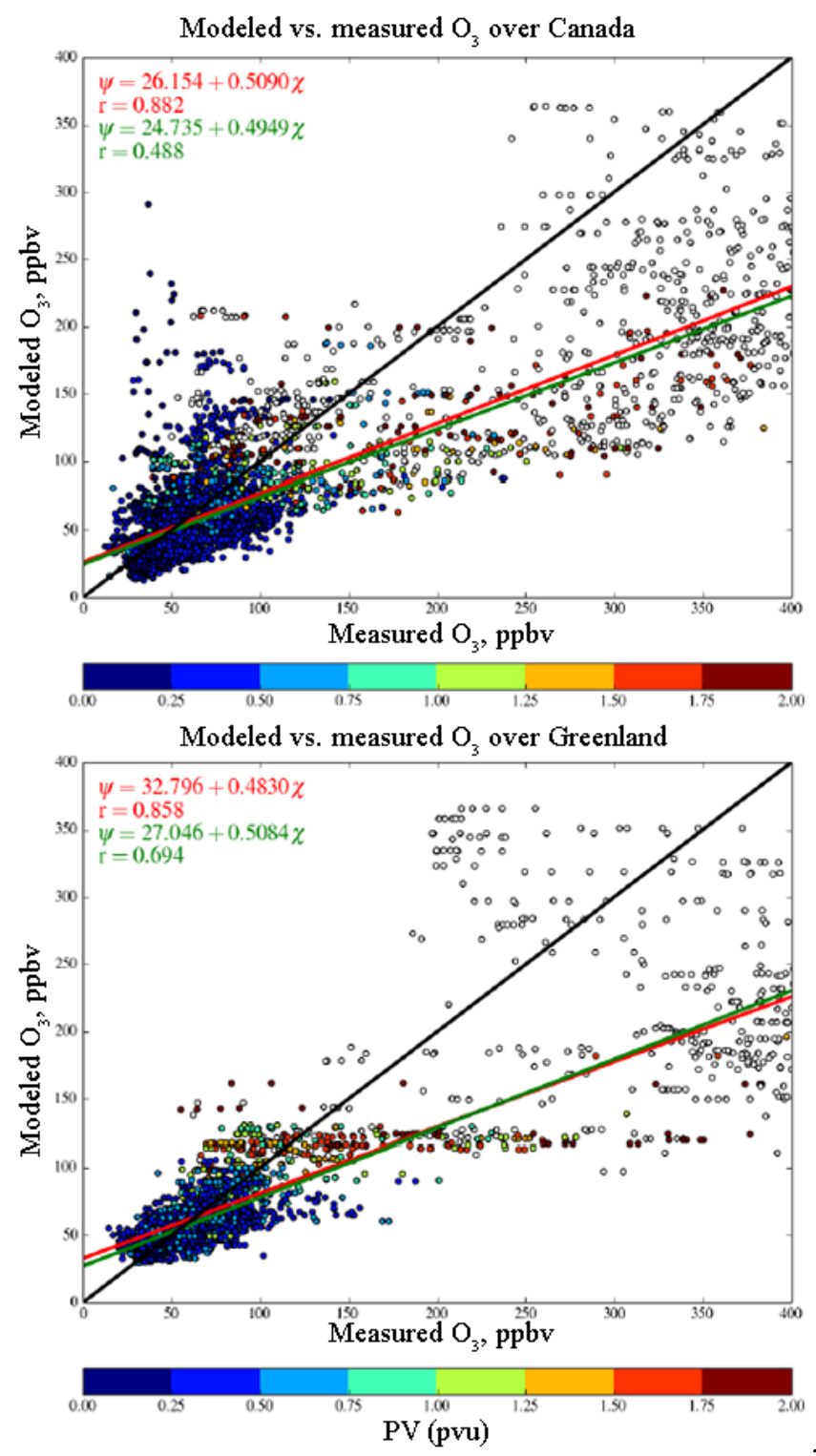

Figure 6. Scatter plot of WRF-Chem modeled vs. measured $\mathrm{O}_{3}$ mixing ratio in ppbv for Canada (top panel) and Greenland (bottom panel) domains. The black lines are the one-to-one line and the PV color scale distinguishes stratospheric (red and white dots) and tropospheric data (blue and green dots). The regression line parameters and the Pearson correlation coefficient with its $p$ value are colored in red and green for the PV range $0-4$ and $0-1 \mathrm{PVu}$, respectively.

tions plotted in Fig. 3 have been divided into several regions using the model CO latitudinal cross sections. The vertical boundaries are defined according to the mean ozone vertical profile in the troposphere, i.e., the depth of the low ozone values layer in the lower troposphere and the downward extent of the tropopause region. The variability of the $\mathrm{CO}$ distribution is only taken from the model, since CO data is not available for many of the ozone observations (ozonesonde and lidar profiles).

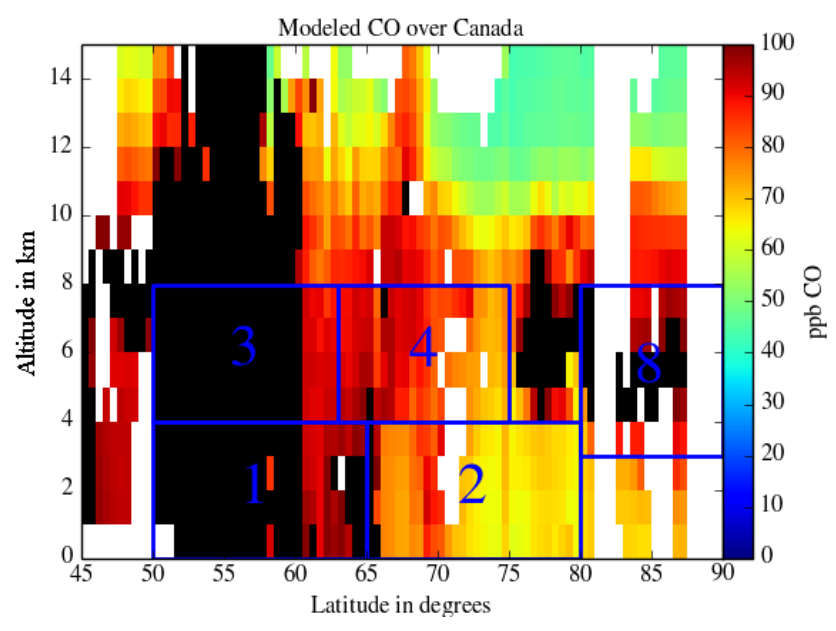

Figure 7. Latitudinal cross section of the modeled $\mathrm{CO}$ mixing ratio in ppbv over Canada for the measurement of spatiotemporal distribution from the June-July 2008 WRF-Chem simulation. The blue boxes correspond to the regions where data are averaged for discussing vertical and latitudinal gradients in Table 4.

\subsection{Measurements over Canada}

For the data taken over Canada, five regions were considered to calculate the mean $\mathrm{O}_{3}$ latitudinal gradient. They correspond to the blue boxes with the labels $1,2,3,4$, and 8 shown in the CO latitudinal distribution plotted in Fig. 7. The different zones have similar regional extent in order to make them comparable. Two are below $4 \mathrm{~km}$ in the altitude range where the lowest ozone values were recorded for latitudes $>60^{\circ} \mathrm{N}$. The boundary between these two boxes is set according to the strong $\mathrm{CO}$ latitudinal difference, due to the biomass burning emissions south of $65^{\circ} \mathrm{N}$ and lack of local emissions of ozone precursors in the region between 65 and $80^{\circ} \mathrm{N}$. In the altitude range $4-8 \mathrm{~km}$, which corresponds to the largest tropospheric ozone values, two other regions were defined. The latitude boundary at $63^{\circ} \mathrm{N}$ is again prescribed according to the latitude where $\mathrm{CO}$ and $\mathrm{O}_{3}$ concentrations are simultaneously decreasing. The last box corresponds to the tropospheric observations at high latitudes $\left(>80^{\circ} \mathrm{N}\right)$ where $\mathrm{CO}$ concentrations are increasing, especially in the altitude range $3-8 \mathrm{~km}$. These ozone observations were mainly made in northeastern Canada by the DC- 8 aircraft. The CO distribution derived from the WRF-Chem simulation is consistent with the analysis of CO observations by Bian et al. (2013), who show the major influence of boreal and Asian emissions on the ARCTAS-B CO observations.

The mean and median measured $\mathrm{O}_{3}$ mixing ratios for the different boxes are shown in Table 3, along with the number of observations from the different measurement techniques (lidar, in situ, and sondes). The mean and median $\mathrm{O}_{3}$ and $\mathrm{CO}$ mixing ratios from the model are also reported in Table 4 and the statistics relevant to the model evaluation are reported in Table 5. The -10 to $-15 \mathrm{ppbv}$ differences between the 
Table 4. Same as Table 3 for the WRF-Chem model $\mathrm{O}_{3}$, $\mathrm{CO}$ mixing ratio, and PV 75 th percentile.

\begin{tabular}{lrrrrrrrr}
\hline $\begin{array}{l}\text { Zone } \\
\mathrm{N}^{\circ}\end{array}$ & $\begin{array}{r}\text { Latitude } \\
\text { range }\end{array}$ & $\begin{array}{r}\text { Longitude } \\
\text { range }\end{array}$ & $\begin{array}{r}\text { Altitude } \\
\mathrm{km}\end{array}$ & $\begin{array}{r}\mathrm{O}_{3} \text { mean } \\
\mathrm{ppbv}\end{array}$ & $\begin{array}{r}\mathrm{O}_{3} \text { median } \\
\mathrm{ppbv}\end{array}$ & $\begin{array}{r}\mathrm{CO} \text { mean } \\
\mathrm{ppbv}\end{array}$ & $\begin{array}{r}\text { CO median } \\
\mathrm{ppbv}\end{array}$ & $\begin{array}{r}\mathrm{PV} 75 \text { th } \\
\mathrm{PVu}\end{array}$ \\
\hline 1 & $50-65^{\circ} \mathrm{N}$ & -132 to $-70^{\circ} \mathrm{W}$ & $0-4$ & 45.9 & 42.9 & 441.5 & 129.6 & - \\
2 & $65-80^{\circ} \mathrm{N}$ & -132 to $-70^{\circ} \mathrm{W}$ & $0-4$ & 38.3 & 37.7 & 71.8 & 67.8 & - \\
3 & $50-63^{\circ} \mathrm{N}$ & -132 to $-70^{\circ} \mathrm{W}$ & $4-8$ & 60.4 & 55.4 & 509.7 & 129.0 & 0.35 \\
4 & $63-75^{\circ} \mathrm{N}$ & -132 to $-70^{\circ} \mathrm{W}$ & 4.8 & 45.7 & 47.9 & 87.8 & 87.6 & 0.31 \\
\hline 5 & $60-80^{\circ} \mathrm{N}$ & -70 to $-20^{\circ} \mathrm{W}$ & $0-4$ & 45.5 & 45.6 & 66.4 & 66.1 & - \\
6 & $57-65^{\circ} \mathrm{N}$ & -70 to $-20^{\circ} \mathrm{W}$ & $4-8$ & 51.4 & 49.0 & 83.9 & 78.8 & 0.45 \\
7 & $65-75^{\circ} \mathrm{N}$ & -70 to $-20^{\circ} \mathrm{W}$ & $4-8$ & 62.8 & 61.1 & 76.2 & 75.8 & 0.44 \\
\hline 8 & $80-87^{\circ} \mathrm{N}$ & -132 to $-20^{\circ} \mathrm{W}$ & $3-8$ & 57.7 & 58.0 & 100.0 & 98.7 & 0.53 \\
\hline
\end{tabular}

Table 5. Metrics of the WRF-Chem $\mathrm{O}_{3}$ simulation performance for the regions reported in Table 4: mean bias, root mean square error (RMSE), normalized mean bias.

\begin{tabular}{lrrrrrr}
\hline $\begin{array}{l}\text { Zone } \\
\mathrm{N}^{\circ}\end{array}$ & $\begin{array}{r}\text { Latitude } \\
\text { range }\end{array}$ & $\begin{array}{r}\text { Longitude } \\
\text { range }\end{array}$ & $\begin{array}{r}\text { Altitude } \\
\mathrm{km}\end{array}$ & $\begin{array}{r}\text { Mean bias } \\
\text { ppbv }\end{array}$ & $\begin{array}{r}\text { RMSE } \\
\text { ppbv }\end{array}$ & $\begin{array}{r}\text { Normalized } \\
\text { mean bias, \% }\end{array}$ \\
\hline 1 & $50-65^{\circ} \mathrm{N}$ & -132 to $-70^{\circ} \mathrm{W}$ & $0-4$ & 0.1 & 24.0 & 0.3 \\
2 & $65-80^{\circ} \mathrm{N}$ & -132 to $-70^{\circ} \mathrm{W}$ & $0-4$ & -4 & 10.3 & -9.5 \\
3 & $50-63^{\circ} \mathrm{N}$ & -132 to $-70^{\circ} \mathrm{W}$ & $4-8$ & -9 & 24.9 & -12.9 \\
4 & $63-75^{\circ} \mathrm{N}$ & -132 to $-70^{\circ} \mathrm{W}$ & 4.8 & -15 & 21.9 & -28.0 \\
\hline 5 & $60-80^{\circ} \mathrm{N}$ & -70 to $-20^{\circ} \mathrm{W}$ & $0-4$ & 0.4 & 7.5 & 0.8 \\
6 & $57-65^{\circ} \mathrm{N}$ & -70 to $-20^{\circ} \mathrm{W}$ & $4-8$ & -6 & 15.3 & -10.6 \\
7 & $65-75^{\circ} \mathrm{N}$ & -70 to $-20^{\circ} \mathrm{W}$ & $4-8$ & -6 & 17.1 & -8.6 \\
\hline 8 & $80-87^{\circ} \mathrm{N}$ & -132 to $-20^{\circ} \mathrm{W}$ & $3-8$ & -13 & 18.0 & -17.2 \\
\hline
\end{tabular}

model and measured ozone in zones 3, 4, and 8 above $4 \mathrm{~km}$ are consistent with the bias of the model in the troposphere over Canada discussed in the previous section. This bias is small $(0$ to $-4 \mathrm{ppbv})$ in the lower troposphere, showing that the emissions used in the model simulation are good enough to calculate the $\mathrm{O}_{3}$ photochemical production.

The negative latitudinal gradient of ozone between zones 3 and $4\left(\Delta \mathrm{O}_{3}=-6 \mathrm{ppbv}\right.$ for the measurements and $\Delta \mathrm{O}_{3} \approx$ $-8 \mathrm{ppbv}$ for the model), and to a lesser extent between zones 1 and $2\left(\Delta \mathrm{O}_{3}=-4 \mathrm{ppbv}\right.$ for the measurements and $\Delta \mathrm{O}_{3}=$ $-5 \mathrm{ppbv}$ for the model), are correlated with a significant negative latitudinal $\mathrm{CO}$ gradient. Here we compare median rather than mean values as the latter are biased by a few very high values (see below). For latitudes lower than $65^{\circ} \mathrm{N}$ there is a strong standard deviation because some of the measurements were taken very close to fresh biomass burning sources (forest fires). Sampling of the biomass burning sources during ARCTAS by the DC- 8 aircraft between 50 and $63^{\circ} \mathrm{N}$ has already been discussed in several papers (Singh et al., 2010; Alvarado et al., 2010; Thomas et al., 2013). In the mid-troposphere the $\mathrm{CO}$ enhancement in zone 3 , where the largest $\mathrm{O}_{3}$ mixing ratio ( $70 \mathrm{ppbv}$ ) is recorded, is $130 \mathrm{ppbv}$, well above the CO tropospheric baseline of $60 \mathrm{ppbv}$ (the strong difference between the mean and the median corre- sponds to the sampling of one biomass burning plume with $\mathrm{CO}>500 \mathrm{ppbv}$, which biases the mean). Zone 8 data in Tables 3 and 4 combines the aircraft sampling over both Canada and Greenland for the high latitude boxes $\left(>80^{\circ} \mathrm{N}\right)$ because they characterize regions with similar $\mathrm{O}_{3}$ and $\mathrm{CO}$ distributions. The $\mathrm{O}_{3}$ mean for zone 8 ( $\left.70 \mathrm{ppbv}\right)$ is similar to the one found in zone 3 , while $\mathrm{CO}$ is increasing again at high latitudes ( $40 \mathrm{ppbv}$ above the $\mathrm{CO}$ tropospheric baseline of 60 ppbv).

The average PV latitudinal cross section is also calculated for the ozone data set as it is a good tracer of the latitudinal variability of the stratospheric $\mathrm{O}_{3}$ source (Fig. 8). Although frequent stratospheric air mass intrusions are seen in the 8 $10 \mathrm{~km}$ altitude range at latitudes higher than $55^{\circ} \mathrm{N}$, the role of the stratospheric source is not clearly visible in the average PV values in the free troposphere. Mean PV values larger than $0.5 \mathrm{PVu}$ are only seen for latitudes higher than $75^{\circ} \mathrm{N}$ in the 3-6 km altitude range (the large PV values at altitudes below $2 \mathrm{~km}$ should not be considered as they are related to the low level cyclonic circulation due the orographic circulation around the Greenland ice cap). This suggests that the latitudinal ozone gradients between zones 3 and 4 are not related to the latitudinal distribution of stratospheric intrusions. However, $\mathrm{O}_{3}$ mixing ratios larger than 70 ppbv (Fig. 3) 


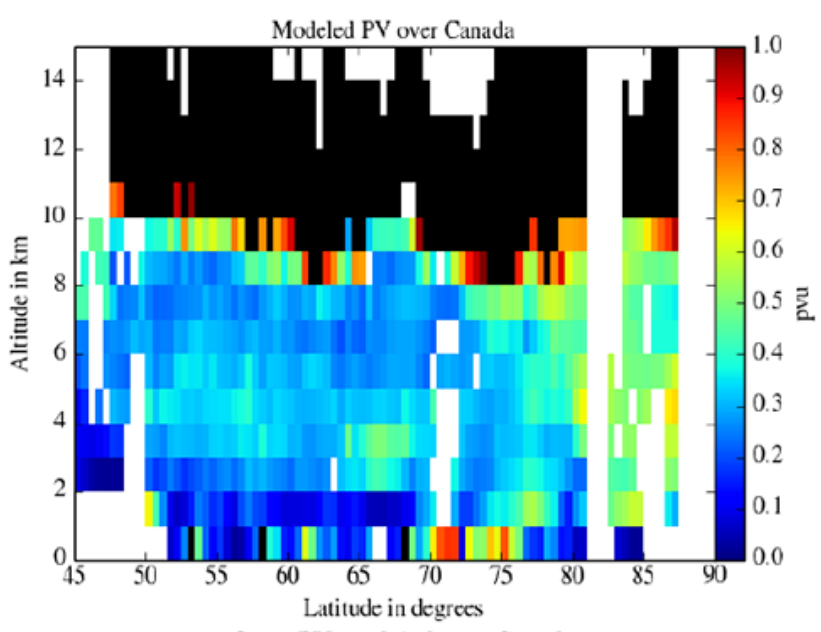

$\mathrm{O}_{3}$ vs $\mathrm{PV}$ modeled over Canada

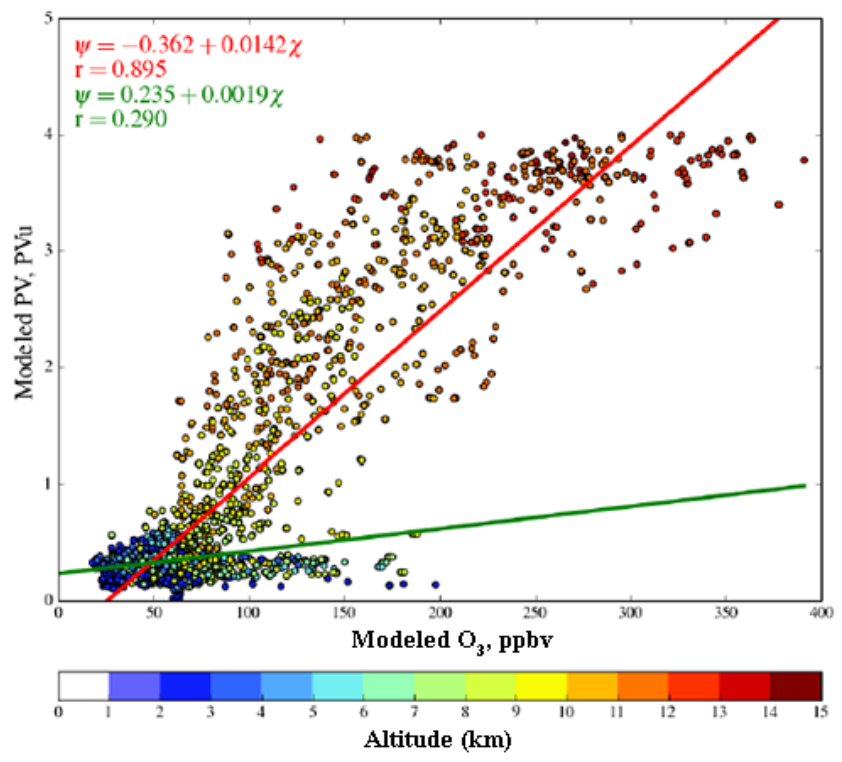

Figure 8. Latitudinal cross section of the average PV profiles over Canada for the summer measurement distribution using the WRFChem simulation (top panel). Scatterplot of modeled $\mathrm{O}_{3}$ in ppbv vs. PV in PVu using an altitude color coded scale (bottom panel). Stratospheric data points with $\mathrm{PV}>4 \mathrm{PVu}$ are not included. The regression line parameters and the Pearson correlation coefficient with its $p$ value are also given for the PV range $0-4 \mathrm{PVu}$ (red) and 0-1 PVu (green).

are correlated with the descending high PV tongue at latitudes between 77 and $87^{\circ} \mathrm{N}$ (Fig. 8). Because the analysis of the ozone spatial distribution shows contrasting behavior of the ozone-PV relationship, it is also necessary to look at the $\mathrm{PV}$ vs. $\mathrm{O}_{3}$ mixing ratio scatter plot. When only tropospheric ozone data are considered $(\mathrm{PV}<1 \mathrm{PVu})$, there is a poor Pearson correlation $(r<0.3)$ between ozone and PV, implying that stratospheric intrusions are not the only source of high tropospheric ozone values (Fig. 8). Indeed one can see that a significant number of high tropospheric ozone mixing ratios

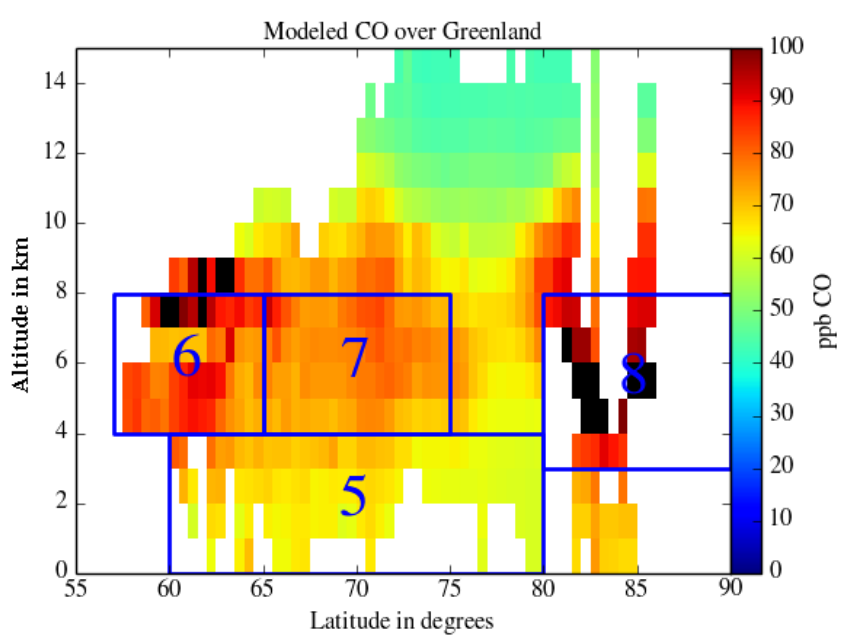

Figure 9. Same as Fig. 7 but for the Greenland region.

(> 70 ppbv) are related to PV less than $1 \mathrm{PVu}$ when using the altitude color scale to separate the UTLS $(8-10 \mathrm{~km})$ and tropospheric data. The difference in the slopes of the regression line, when including or not including the PV values larger than $1 \mathrm{PVu}$ (red vs. green lines in Fig. 8), is also larger than similar variation observed at mid-latitudes in Europe where the $\mathrm{O}_{3}$ to $\mathrm{PV}$ ratio decreases from 30 to $150 \mathrm{ppbv} / \mathrm{PVu}$ (Ravetta et al., 1999). This suggests that the ozone variability during summer 2008 is not driven by the variability of stratospheric air mixed into the free troposphere, but mainly related to emissions and photochemistry over Canada.

\subsection{Measurements over Greenland}

The same procedure was applied to the latitudinal distribution over Greenland. The regions considered for the latitudinal gradient analysis are slightly different because the $\mathrm{CO}$ latitudinal cross sections and the ozone vertical structure are different. The selected regions are shown by the blue boxes in Fig. 9. Only one zone is chosen between 60 and $80^{\circ} \mathrm{N}$ for the altitude range below $4 \mathrm{~km}$, where there are the lowest tropospheric $\mathrm{O}_{3}$ and $\mathrm{CO}$ concentrations values. The $\mathrm{CO}$ latitudinal gradient is indeed very weak in the lower troposphere between 60 and $80^{\circ} \mathrm{N}(<5 \mathrm{ppbv})$. However, as over Canada, two boxes are chosen in the altitude range $4-8 \mathrm{~km}$ because of their differences in terms of $\mathrm{CO}$ and $\mathrm{O}_{3}$ concentrations. An additional box corresponds to the tropospheric observations at high latitudes $\left(>80^{\circ} \mathrm{N}\right)$ where the $\mathrm{CO}$ concentrations are also higher, especially in the altitude range $3-8 \mathrm{~km}$. This is related to the observations mainly made in northwestern Greenland by the DC-8 aircraft.

Table 5 shows that there is no $\mathrm{O}_{3}$ underestimate by the model in the lower troposphere and the model bias above $4 \mathrm{~km}$ is of the order of $-6 \mathrm{ppbv}$. This suggests that the model performance over Greenland, away from the continental sources, is better than over Canada. The remaining 

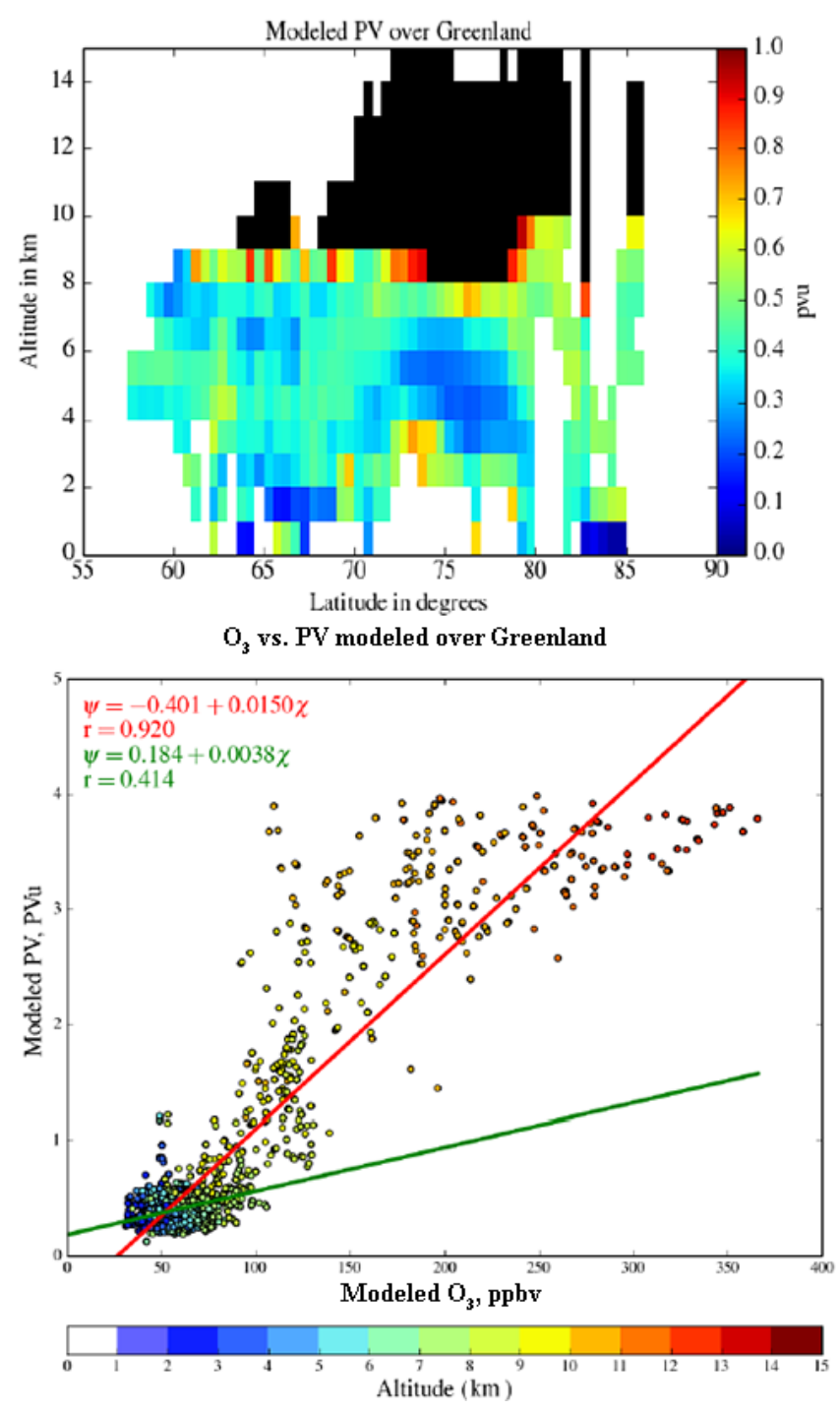

Figure 10. Same as Fig. 8 but for the Greenland region.

-6 ppbv bias can be easily explained by the stratospheric $\mathrm{O}_{3}$ climatology having too low values, while lightning is known to be less important over Greenland (Cecil et al., 2014; Christian et al., 2003). The CO concentration in the lower troposphere (zone 5 of Table 3 ) is close to the tropospheric baseline, while $\mathrm{O}_{3}$ is not markedly different from the values seen over Canada. The positive latitudinal $\mathrm{O}_{3}$ gradient between zones 6 and 7 in the mid-troposphere above $4 \mathrm{~km}$ $\left(\Delta \mathrm{O}_{3}=12 \mathrm{ppbv}\right)$ is two times larger than the latitudinal gradient over Canada, but the overall $\mathrm{O}_{3}$ mid-tropospheric concentration over Greenland is similar to its counterpart over Canada (62 vs. 65 ppbv). The corresponding negative $\mathrm{CO}$ latitudinal gradient between zone 6 and 7 is weak (difference of $8 \mathrm{ppbv}$ ), but it is anticorrelated with the ozone gradient. The $\mathrm{CO}$ excess above baseline is only $20 \mathrm{ppbv}$ in zone 6 , where $\mathrm{CO}$ is maximum. The anticorrelation between the $\mathrm{O}_{3}$ and $\mathrm{CO}$ latitudinal gradient may indicate more occurrences of stratospheric ozone intrusion in zone 7 at latitudes higher than $65^{\circ} \mathrm{N}$ during the POLARCAT period. If the lower CO were due to upwelling of pristine air from the Arctic lower troposphere, it would be accompanied by smaller $\mathrm{O}_{3}$ concentrations according to Fig. 3.

Looking at the average PV distribution extracted from the WRF-Chem simulation (Fig. 10), frequent stratospheric air mass intrusions are seen in the altitude range $8-10 \mathrm{~km}$, especially at $75^{\circ} \mathrm{N}(\mathrm{PV}>1 \mathrm{PVu})$. $\mathrm{PV}$ values are also larger in the mid-troposphere over Greenland than over Canada (75th $\mathrm{PV}$ percentile is $0.45 \mathrm{PVu}$ over Greenland but $0.3 \mathrm{PVu}$ over Canada). The $\mathrm{PV}$ vs. $\mathrm{O}_{3}$ mixing ratio scatter plot also shows a higher Pearson correlation $(r>0.4)$ between ozone and stratospheric intrusion than over Canada (Fig. 10). Compared to the results obtained over Canada, the difference between the $\mathrm{O}_{3}$-to-PV ratio, including $\mathrm{PV}$ values larger than 1 , and that excluding them (red vs. green regression line) is smaller (200 ppbv / PVu instead of $400 \mathrm{ppbv} / \mathrm{PVu}$ for Canada). This is consistent with a larger fraction of ozone from the UTLS over Greenland. However, there is not a significant latitudinal PV gradient in the mid-troposphere between zones 6 and 7 where a positive 12 ppbv ozone latitudinal gradient is detected. At high latitudes above $80^{\circ} \mathrm{N}$, the $\mathrm{PV}$ and $\mathrm{CO}$ latitudinal distribution in the troposphere is almost identical to the latitudinal cross section over Canada (Fig. 8), which supports merging data in a single zone 8 for the statistics reported in Tables 3 and 4 .

\subsection{Discussion}

This section aims to discuss the latitudinal ozone distribution above Greenland and Canada using (i) existing studies of the role of biomass burning, anthropogenic emissions, and STE on high latitude tropospheric ozone, (ii) satellite observations of biomass burning locations and associated plumes during summer 2008, and (iii) back trajectory analysis of the air masses where observations were made.

In the lower troposphere $(0-4 \mathrm{~km})$, the fact that ozone is lower than $50 \mathrm{ppbv}$ everywhere (except close to the fires southwest of Hudson Bay) is expected, considering a near zero net ozone photochemical production $\left(+0.3 \mathrm{ppbv}^{\mathrm{day}}{ }^{-1}\right.$ near the surface and $-0.3 \mathrm{ppbv} \mathrm{day}^{-1}$ in the lowermost free troposphere) and a weak influence of STE below $5 \mathrm{~km}$ in Northern Canada (Walker et al., 2012; Mauzerall et al., 1996).

In the free troposphere above $4 \mathrm{~km}$, a negative $\mathrm{CO}$ latitudinal gradient in the latitude range $50-75^{\circ} \mathrm{N}$ is seen over both Greenland and Canada. The large CO latitudinal gradient over Canada can only be explained when considering the biomass burning plume at the continental scale which is superimposed onto the anthropogenic emissions south of $50^{\circ} \mathrm{N}$. The position of the biomass burning plume is shown by the MODIS monthly mean aerosol optical depth, together with the Canadian Forest Service (CFS) fire counts (Fig. 11). Maxima of aerosol optical depth are seen both southwest 

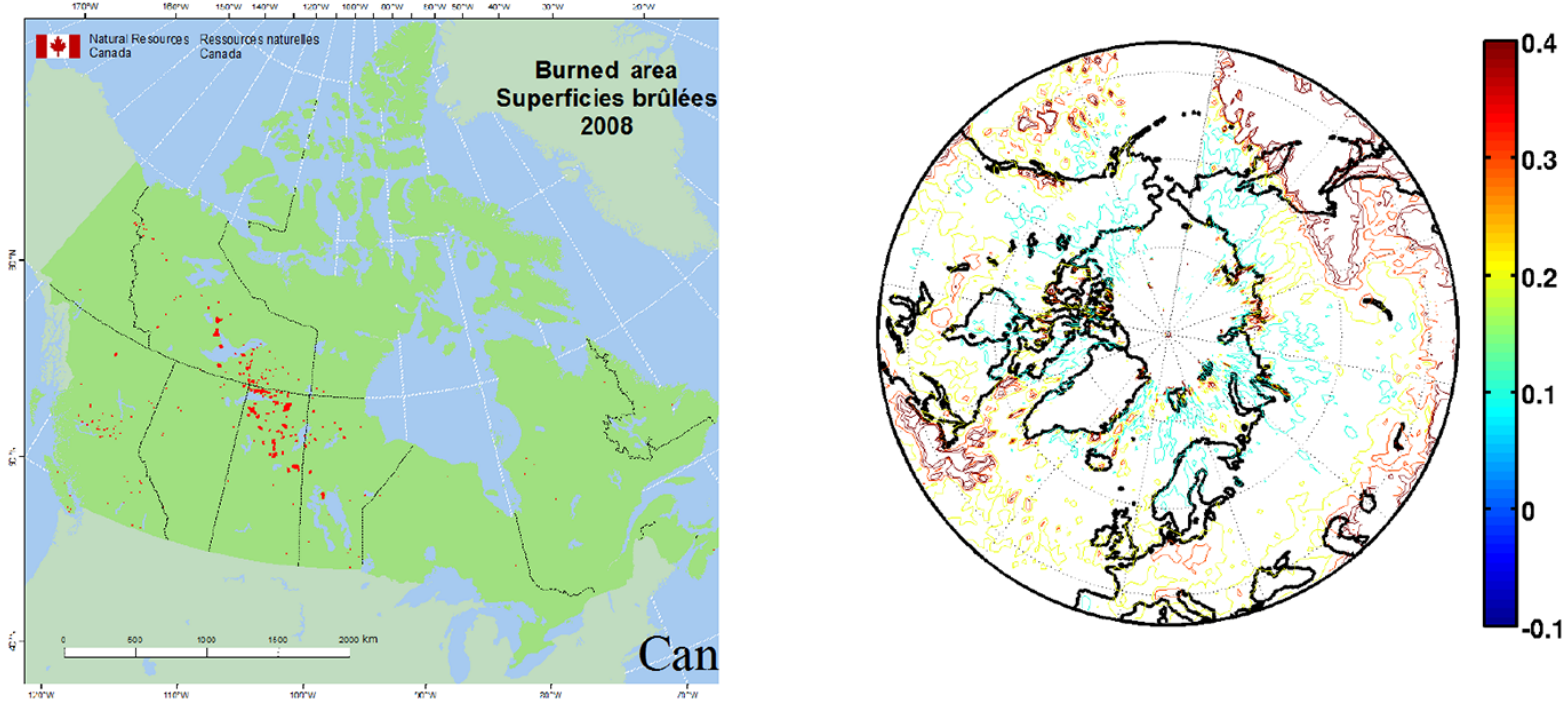

Figure 11. Map of the Canadian Forest Service fire counts in red for summer 2008 (left) and MODIS aerosol optical depth at $0.55 \mu \mathrm{m}$ from 15 June to 15 July 2008 (right).
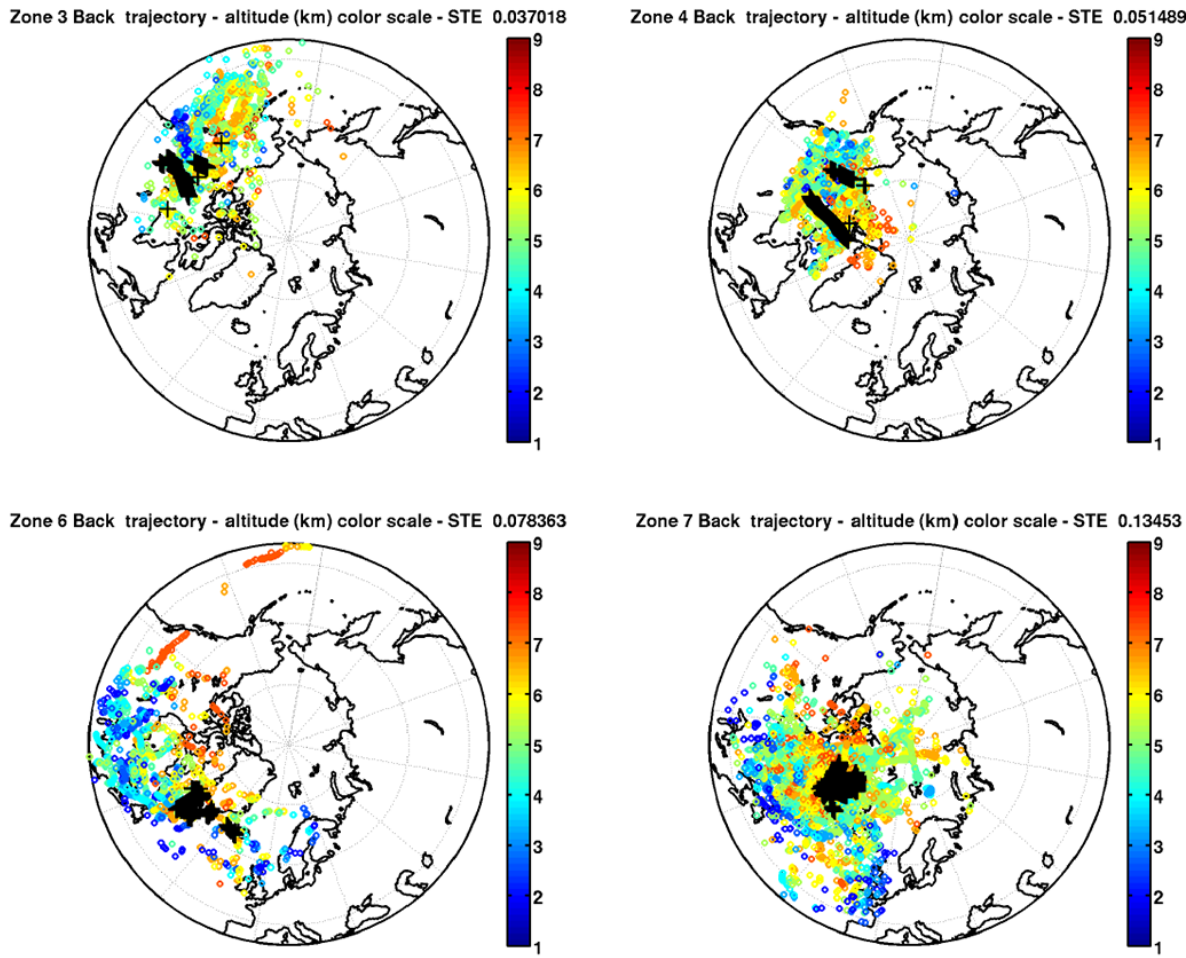

Figure 12. Map of the air mass daily positions using 4 days FLEXTRA trajectories, which correspond to the observations in zones 3 and 4 over Canada (top row) and in zones 6 and 7 over Greenland (bottom row). Black crosses show the measurement positions and the color scale is the air mass altitude in $\mathrm{km}$. The fraction is the relative number of trajectory positions reaching the tropopause (PV $=1.5 \mathrm{PVu})$.

of Hudson Bay and over the Atlantic Ocean in the latitude band 50 to $60^{\circ} \mathrm{N}$. The ozone latitudinal gradient is also negative and correlated with $\mathrm{CO}$ over Canada, which can be explained by ozone photochemical production in the Canadian biomass burning plumes. Thomas et al. (2013) showed a 3 ppbv ozone increase downwind of biomass burning emissions and an enhancement ratio $\Delta \mathrm{O}_{3} / \Delta \mathrm{CO}$ ranging from 0.1 near the fires to 0.5 downwind from the fires. This is consistent with a $\Delta \mathrm{O}_{3}$ of $6-8$ ppbv between zone 3 and 4 over Canada where a $40 \mathrm{ppbv}$ difference in the median $\mathrm{CO}$ value 


\section{Zone 8 Back trajectory - altitude $(\mathrm{km})$ color scale - STE 0.13977}

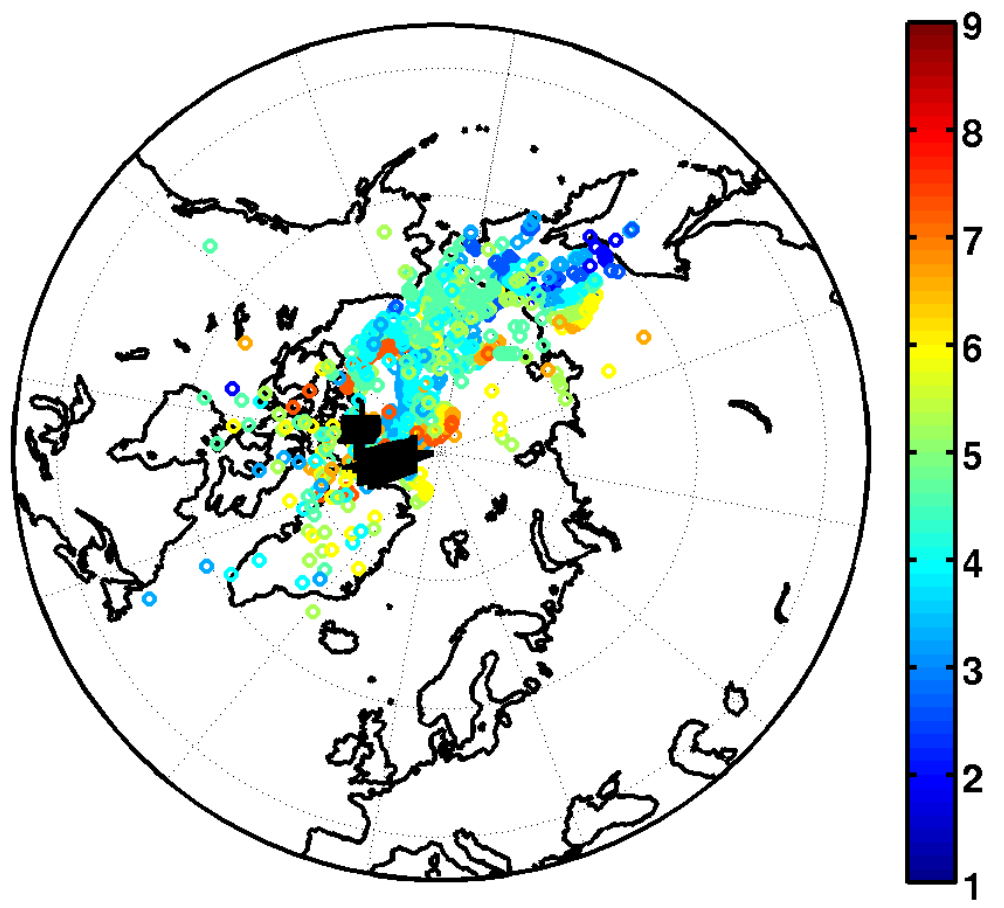

Figure 13. Same as Fig. 12 for the observations at latitudes $>80^{\circ} \mathrm{N}$ in zone 8 .

is found in the model simulation. The contribution of other emission sources can be also estimated using 4 day backward trajectories calculated with the FLEXTRA model and T213/L91 ECMWF analysis (Fig. 12). According to the upper panels of Fig. 12, long-range transport into zones 3 and 4 over Canada shows similar patterns with $75 \%$ of the air masses coming from North American mid-latitudes, i.e., the area between -60 and $-150^{\circ} \mathrm{W}$ and 50 and $70^{\circ} \mathrm{N}$. Regional variability of STE also has a weak influence during this period, considering the weak dependency of $\mathrm{O}_{3}$ with $\mathrm{PV}$ over Canada. Local emissions from biomass burning are the most reasonable explanation for the ozone latitudinal gradient between 50 and $75^{\circ} \mathrm{N}$.

Over southern Greenland the effect of ozone photochemical production related to fire plumes and the North American anthropogenic emissions appears to be less than 4 ppbv, considering the weak $\mathrm{CO}$ gradient between zones 6 and 7 $\left(\approx-8\right.$ ppbv). The negative $\mathrm{O}_{3}$ gradient due to increased photochemical production in zone 6 can then be easily counterbalanced by another source in zone 7 to explain the positive latitudinal $\mathrm{O}_{3}$ gradient over Greenland. The STE ozone source is a likely contributor, as suggested by the better correlation between $\mathrm{O}_{3}$ and $\mathrm{PV}$ over Greenland than Canada and larger PV over Greenland. Frequent tropopause polar vortices developing over Baffin Bay and Davis Strait still occur during the summer period because of the important role of radiation to maintain and intensify the upper troposphere cyclonic activity during the summer (Cavallo and Hakim,
2010). However, in the absence of a clear PV latitudinal gradient between 55 and $75^{\circ} \mathrm{N}$ in the model, simulation cannot explain the significant +12 ppbv ozone latitudinal gradient. Therefore, while STE certainly contributes to the ozone budget over both southern and northern Greenland, it does not explain the largest $\mathrm{O}_{3}$ values found in zone 7 . Looking at the long-range transport plot for zones 6 and 7 (lower panels of Fig. 12), the fraction of air masses coming from the North American mid-latitude area are now 34 and $18 \%$, respectively. Multiple mid-latitude sources, including North America, Europe, and even Asia, are also related to ozone observations in zone 7, and may explain the differences in ozone production efficiency between zone 6 and zone 7 . Wespes et al. (2012) concluded using the Model MOZART-4 that anthropogenic pollution from Europe dominates $\mathrm{O}_{3}$ concentrations in summer 2008 in the Arctic, while Roiger et al. (2011) shows, using aircraft measurements, that Asian anthropogenic pollution can be mixed with stratospheric air masses over Greenland in the $75-80^{\circ}$ latitude band.

For the free troposphere at high latitudes above $80^{\circ} \mathrm{N}$, the STE contribution is maximum in this region for the 4$8 \mathrm{~km}$ altitude range according to the average PV distribution shown in Fig. 8 or Fig. 10. The 75th percentile of the PV distribution is also $>0.5 \mathrm{PVu}$ in zone 8 , while it is $0.3 \mathrm{PVu}$ at latitudes lower than $75^{\circ}$ over Canada and $0.4 \mathrm{PVu}$ over Greenland. Zängl and Hoinka (2001) discussed the horizontal gradient of the tropopause height over the Arctic using ECMWF analysis and radiosondes. The region with 
the largest horizontal gradient is displaced to the north near $80^{\circ} \mathrm{N}$ in July over North America, while vertical tilting of the isentropic surfaces remains small. These conditions are favorable for isentropic motion across the tropopause with more efficient STE. However CO also increases at high latitude because of transport from Asian and northern Siberian pollution sources, according to the air mass transport pathway for zone 8 (Fig. 13). Such a mixture of stratospheric $\mathrm{O}_{3}$ and Asian pollution has already been suggested by Roiger et al. (2011) to explain the ozone concentrations observed at very high latitudes in the Arctic. Our study, using more ozone measurements, leads to the same conclusions.

\section{Conclusions}

The purpose of this work is to provide a complete picture of Arctic ozone using measurements available during the summer 2008 POLARCAT campaigns over Canada and Greenland, where three aircraft were deployed and seven ozonesonde stations intensified their ozone vertical profiling. This is the first case of such complete temporal and geographical coverage. We take advantage of the large number of airborne lidar profiles (representing $67 \%$ of the $\mathrm{O}_{3}$ measurements over Canada and $26 \%$ over Greenland). The measured ozone climatology established in this paper can also be used for future model evaluation at high latitudes. For example, in our work, while good correspondence of the measured $\mathrm{O}_{3}$ vertical and latitudinal distribution is found with model results from WRF-Chem, a negative $\mathrm{O}_{3}$ bias of -6 to -15 ppbv between the model and the observations is found in the free troposphere over $4 \mathrm{~km}$, especially over Canada. This deficiency is partly related to the WRF-Chem model stratospheric ozone initialization.

The WRF-Chem model simulation is also used to discuss the relative influence of tropospheric ozone sources at high latitude in summer. Ozone average concentrations are of the order of $65 \mathrm{ppbv}$ at altitudes above $4 \mathrm{~km}$ both over Canada and Greenland, while they are less than $50 \mathrm{ppbv}$ in the lower troposphere. For Canada, the analysis of the modeled CO distribution and the weak correlation $(<30 \%)$ of $\mathrm{O}_{3}$ and PV suggest that stratosphere-troposphere exchange (STE) is not the major contribution to tropospheric ozone at latitudes less than $70^{\circ} \mathrm{N}$, where transport of North American biomass burning (BB) emissions took place during the 2008 summer. Conversely, significant STE is found over Greenland according to the better $\mathrm{O}_{3}$ vs. PV correlation (>40\%) and the higher value of the 75th PV percentile. This is related to the persistence of cyclonic activity over Baffin Bay during the summer.
A weak negative latitudinal summer ozone gradient of -6 to $-8 \mathrm{ppbv}$ is found over Canada in the mid-troposphere between 4 and $8 \mathrm{~km}$ because the $\mathrm{O}_{3}$ photochemical production from $\mathrm{BB}$ emissions mainly takes place at latitudes less than $65^{\circ} \mathrm{N}$, while STE plays a larger role at latitudes higher than $70^{\circ} \mathrm{N}$. A positive ozone latitudinal gradient of $12 \mathrm{ppbv}$ is observed in the same altitude range over Greenland not because of an increasing latitudinal influence of STE, but because of different long-range transport from multiple mid-latitude sources (North America, Europe, and even Asia for latitudes higher than $77^{\circ} \mathrm{N}$ ).

For the Arctic latitudes $\left(>80^{\circ} \mathrm{N}\right)$, free tropospheric $\mathrm{O}_{3}$ concentrations are related to a mixture of stratospheric $\mathrm{O}_{3}$ transport across the tropopause and Asian pollution, as already suggested by Roiger et al. (2011) using a case study of aircraft observations in the Arctic. Our study, which uses more ozone measurements, leads to the same conclusions.

\section{Data availability}

The CNRS ATR-42 aircraft ozone lidar observations can be downloaded from ftp://polarcat@ftp.aero.jussieu. fr/Kanger/LidarO3/ (Ancellet, 2009a) and the the metadata file is called "ReadmeO3lidardata". The CNRS ATR42 ozone in-situ measurements from the MOZART instrument are deposited on ftp://ftp.aero.jussieu.fr/Kanger/ Data_ATR/ (Ancellet, 2009b) and the meta-data file is called "Readme_MOZART.txt". Requested password is "kanger" to access the CNRS data. The data from the NASA DC-8 aircraft have been downloaded from the NASA archive website, using a direct Link to the DIAL data archive (http://www-air.larc.nasa.gov/cgi-bin/ ArcView/arctas\#HAIR.JOHN/, Hair, 2008) and to the ozone in-situ measurements (http://www-air.larc.nasa.gov/cgi-bin/ ArcView/arctas\#WEINHEIMER.ANDREW/, ). No passwords are required as this is open and public access. The POLARCAT ozone data for DLR Falcon-20 is available from the HALO/Falcon database (https://halo-db.pa.op.dlr. de/). ECC ozonesonde data have been downloaded from the ARCIONS web site ftp://es-ee.tor.ec.gc.ca/pub/ftpdt/ ARC-IONSData/summer/ICARTT/ (Tarasick, 2008) and the WOUDC web site (http://woudc.org/data/explore.php?lang= en). Data files from the WRF model simulation are too big to be publicly available but could be obtained from LATMOS. Air mass trajectories are calculated with ECMWF meteorological analysis downloaded from ECMWF MARS data base which is not publicly available. 
Acknowledgements. We are very grateful to the support of the Meteo France/CNRS/CNES UMS SAFIRE for the ATR-42 aircraft deployment over Greenland. This work was supported by funding from ANR and LEFE INSU/CNRS (CLIMSLIP project) and from the ICE-ARC programme from the European Union 7th Framework Programme, grant number 603887. The FLEXTRA team (A. Stohl, and co-workers) is acknowledged for providing and supporting the FLEXTRA code. NASA and DLR are acknowledged for their support of the deployment of the DC-8 and Falcon-20 aircraft. WOUDC and the NASA MODIS team are acknowledged for providing the ozonesonde data and the MODIS data, respectively.

Edited by: E. Harris

Reviewed by: two anonymous referees

\section{References}

Abbatt, J. P. D., Thomas, J. L., Abrahamsson, K., Boxe, C., Granfors, A., Jones, A. E., King, M. D., Saiz-Lopez, A., Shepson, P. B., Sodeau, J., Toohey, D. W., Toubin, C., von Glasow, R., Wren, S. N., and Yang, X.: Halogen activation via interactions with environmental ice and snow in the polar lower troposphere and other regions, Atmos. Chem. Phys., 12, 6237-6271, doi:10.5194/acp-12-6237-2012, 2012.

Alvarado, M. J., Logan, J. A., Mao, J., Apel, E., Riemer, D., Blake, D., Cohen, R. C., Min, K.-E., Perring, A. E., Browne, E. C., Wooldridge, P. J., Diskin, G. S., Sachse, G. W., Fuelberg, H., Sessions, W. R., Harrigan, D. L., Huey, G., Liao, J., Case-Hanks, A., Jimenez, J. L., Cubison, M. J., Vay, S. A., Weinheimer, A. J., Knapp, D. J., Montzka, D. D., Flocke, F. M., Pollack, I. B., Wennberg, P. O., Kurten, A., Crounse, J., Clair, J. M. St., Wisthaler, A., Mikoviny, T., Yantosca, R. M., Carouge, C. C., and Le Sager, P.: Nitrogen oxides and PAN in plumes from boreal fires during ARCTAS-B and their impact on ozone: an integrated analysis of aircraft and satellite observations, Atmos. Chem. Phys., 10, 9739-9760, doi:10.5194/acp-10-9739-2010, 2010.

AMAP: Assessment 2015: Black carbon and ozone as Arctic climate forcers. Arctic Monitoring and Assessment Programme (AMAP), Arctic Monitoring and Assessment Programme (AMAP), Oslo, Norway, 1-116, available at: http://www.amap.no/documents/doc/, 2015.

Ancellet, G.: CNRS ATR-42 aircraft ozone lidar observations, LATMOS/IPSL, UPMC Univ. Paris 06 Sorbonne Université, UVSQ, CNRS, Paris, France, available: ftp://polarcat@ftp.aero.jussieu. fr/Kanger/LidarO3/, 2009a.

Ancellet, G.: CNRS ATR-42 ozone in-situ measurements, LATMOS/IPSL, UPMC Univ. Paris 06 Sorbonne Universités, UVSQ, CNRS, Paris, France, avilable at: ftp://ftp.aero.jussieu.fr/Kanger/ Data_ATR/, 2009b.

Ancellet, G. and Ravetta, F.: Compact airborne lidar for tropospheric ozone: description and field measurements, Appl. Opt., 37, 5509-5521, doi:10.1364/AO.37.005509, 1998.

Ancellet, G. and Ravetta, F.: On the usefulness of an airborne lidar for O3 layer analysis in the free troposphere and the planetary boundary layer, J. Environ. Monit., 5, 47-56, doi:10.1039/B205727A, 2003.

Bian, H., Colarco, P. R., Chin, M., Chen, G., Rodriguez, J. M., Liang, Q., Blake, D., Chu, D. A., da Silva, A., Darmenov, A.
S., Diskin, G., Fuelberg, H. E., Huey, G., Kondo, Y., Nielsen, J. E., Pan, X., and Wisthaler, A.: Source attributions of pollution to the Western Arctic during the NASA ARCTAS field campaign, Atmos. Chem. Phys., 13, 4707-4721, doi:10.5194/acp-13-47072013, 2013.

Browell, E., Carter, A., Shipley, S., Allen, R., Butler, C., Mayo, M., Siviter Jr., J., and Hall, W.: NASA multipurpose airborne DIAL system and measurements of ozone and aerosol profiles, Appl. Opt., 22, 522-534, doi:10.1364/AO.22.000522, 1983.

Browell, E., Ismail, S., and Shipley, S.: Ultraviolet DIAL measurements of $\mathrm{O}_{3}$ profiles in regions of spatially inhomogeneous aerosols, Appl. Opt., 24, 2827-2836, doi:10.1364/AO.24.002827, 1985.

Browell, E. V., Hair, J. W., Butler, C. F., Grant, W. B., DeYoung, R. J., Fenn, M. A., Brackett, V. G., Clayton, M. B., Brasseur, L. A., Harper, D. B., Ridley, B. A., Klonecki, A. A., Hess, P. G., Emmons, L. K., Tie, X., Atlas, E. L., Cantrell, C. A., Wimmers, A. J., Blake, D. R., Coffey, M. T., Hannigan, J. W., Dibb, J. E., Talbot, R. W., Flocke, F., Weinheimer, A. J., Fried, A., Wert, B., Snow, J. A., and Lefer, B. L.: Ozone, aerosol, potential vorticity, and trace gas trends observed at high-latitudes over North America from February to May 2000, J. Geophys. Res.-Atmos., 108, 8369, doi:10.1029/2001JD001390, 2003.

Buhaug, O., Corbett, J., Endresen, O., Eyring, V., Faber, J., Hanayama, S., Lee, D. S., Lee, D., Lindstad, H., Markowska, A., Mjelde, A., Nelissen, D., Nilsen, J., Palsson, C., Winebrake, J., Wu, W., and Yoshida, K.: Second IMO GHG study 2009, International Maritime Organization (IMO) London, UK, Tech. Report, 2009.

Cavallo, S. M. and Hakim, G. J.: Composite Structure of Tropopause Polar Cyclones, Mon. Weather Rev., 138, 3840 3857, doi:10.1175/2010MWR3371.1, 2010.

Cecil, D. J., Buechler, D. E., and Blakeslee, R. J.: Gridded lightning climatology from TRMM-LIS and OTD: Dataset description, Atmos. Res., 135-136, 404-414, doi:10.1016/j.atmosres.2012.06.028, 2014.

Chou, M.-D. and Suarez, M. J.: An efficient thermal infrared radiation parameterization for use in general circulation models, NASA Tech. Memorandum 104606-Vol 3, NASA, Goddard Space Flight Center, Greenbelt, MD, 1994.

Christian, H. J., Blakeslee, R. J., Boccippio, D. J., Boeck, W. L., Buechler, D. E., Driscoll, K. T., Goodman, S. J., Hall, J. M., Koshak, W. J., Mach, D. M., and Stewart, M. F.: Global frequency and distribution of lightning as observed from space by the Optical Transient Detector, J. Geophys. Res.-Atmos., 108, 4005, doi:10.1029/2002JD002347, 2003.

Cooper, O. R., Parrish, D. D., Stohl, A., Trainer, M., Nedelec, P., Thouret, V., Cammas, J. P., Oltmans, S. J., Johnson, B. J., Tarasick, D., Leblanc, T., McDermid, I. S., Jaffe, D., Gao, R., Stith, J., Ryerson, T., Aikin, K., Campos, T., Weinheimer, A., and Avery, M. A.: Increasing springtime ozone mixing ratios in the free troposphere over western North America, Nature, 463, 344-348, doi:10.1038/nature08708, 2010.

Crutzen, P., Lawrence, M., and Pöschl, U.: On the background photochemistry of tropospheric ozone, Tellus B, 51, 123-146, doi:10.3402/tellusb.v51i1.16264, 1999.

Dupont, R., Pierce, B., Worden, J., Hair, J., Fenn, M., Hamer, P., Natarajan, M., Schaack, T., Lenzen, A., Apel, E., Dibb, J., Diskin, G., Huey, G., Weinheimer, A., Kondo, Y., and Knapp, 
D.: Attribution and evolution of ozone from Asian wild fires using satellite and aircraft measurements during the ARCTAS campaign, Atmos. Chem. Phys., 12, 169-188, doi:10.5194/acp-12169-2012, 2012.

Emmons, L. K., Walters, S., Hess, P. G., Lamarque, J.-F., Pfister, G. G., Fillmore, D., Granier, C., Guenther, A., Kinnison, D., Laepple, T., Orlando, J., Tie, X., Tyndall, G., Wiedinmyer, C., Baughcum, S. L., and Kloster, S.: Description and evaluation of the Model for Ozone and Related chemical Tracers, version 4 (MOZART-4), Geosci. Model Dev., 3, 43-67, doi:10.5194/gmd3-43-2010, 2010.

Fast, J. D., Gustafson, W. I., Easter, R. C., Zaveri, R. A., Barnard, J. C., Chapman, E. G., Grell, G. A., and Peckham, S. E.: Evolution of ozone, particulates, and aerosol direct radiative forcing in the vicinity of Houston using a fully coupled meteorology-chemistry-aerosol model, J. Geophys. Res.-Atmos., 111, D21305, doi:10.1029/2005JD006721, 2006.

Froidevaux, L., Jiang, Y. B., Lambert, A., Livesey, N. J., Read, W. G., Waters, J. W., Browell, E. V., Hair, J. W., Avery, M. A., McGee, T. J., Twigg, L. W., Sumnicht, G. K., Jucks, K. W., Margitan, J. J., Sen, B., Stachnik, R. A., Toon, G. C., Bernath, P. F., Boone, C. D., Walker, K. A., Filipiak, M. J., Harwood, R. S., Fuller, R. A., Manney, G. L., Schwartz, M. J., Daffer, W. H., Drouin, B. J., Cofield, R. E., Cuddy, D. T., Jarnot, R. F., Knosp, B. W., Perun, V. S., Snyder, W. V., Stek, P. C., Thurstans, R. P., and Wagner, P. A.: Validation of Aura Microwave Limb Sounder stratospheric ozone measurements, J. Geophys. Res.Atmos., 113, D5S20, doi:10.1029/2007JD008771, 2008.

Granier, C., Niemeier, U., Jungclaus, J. H., Emmons, L., Hess, P., Lamarque, J.-F., Walters, S., and Brasseur, G. P.: Ozone pollution from future ship traffic in the Arctic northern passages, Geophys. Res. Lett., 33, L13807, doi:10.1029/2006GL026180, 2006.

Grell, G. and Dévényi, D.: A generalized approach to parameterizing convection combining ensemble and data assimilation techniques, Geophys. Res. Lett., 29, 1693, doi:10.1029/2002GL015311, 2002.

Grell, G. A., Peckham, S. E., Schmitz, R., McKeen, S. A., Frost, G., Skamarock, W. C., and Eder, B.: Fully coupled online chemistry within the WRF model, Atmos. Environ., 39, 6957-6975, doi:10.1016/j.atmosenv.2005.04.027, 2005.

Guenther, A. B., Jiang, X., Heald, C. L., Sakulyanontvittaya, T., Duhl, T., Emmons, L. K., and Wang, X.: The Model of Emissions of Gases and Aerosols from Nature version 2.1 (MEGAN2.1): an extended and updated framework for modeling biogenic emissions, Geosci. Model Dev., 5, 1471-1492, doi:10.5194/gmd-51471-2012, 2012.

Hair, F.: NASA DC-8 aircraft data, DIAL data archive, NASA Langley Reasearch Center, Hampton, VA, USA, available at: http://www-air.larc.nasa.gov/cgi-bin/ArcView/arctas\#HAIR. JOHN/, 2008.

Hess, P. G. and Zbinden, R.: Stratospheric impact on tropospheric ozone variability and trends: 1990-2009, Atmos. Chem. Phys., 13, 649-674, doi:10.5194/acp-13-649-2013, 2013.

Hong, S.-Y., Noh, Y., and Dudhia, J.: A New Vertical Diffusion Package with an Explicit Treatment of Entrainment Processes, Mon. Weather Rev.., 134, 2318-2341, doi:10.1175/MWR3199.1, 2006.

Honrath, R. E., Peterson, M. C., Guo, S., Dibb, J. E., Shepson, P. B., and Campbell, B.: Evidence of $\mathrm{NO}_{x}$ production within or upon ice particles in the Greenland snowpack, Geophys. Res. Lett., 26, 695-698, doi:10.1029/1999GL900077, 1999.

Jacob, D. J., Crawford, J. H., Maring, H., Clarke, A. D., Dibb, J. E., Emmons, L. K., Ferrare, R. A., Hostetler, C. A., Russell, P. B., Singh, H. B., Thompson, A. M., Shaw, G. E., McCauley, E., Pederson, J. R., and Fisher, J. A.: The Arctic Research of the Composition of the Troposphere from Aircraft and Satellites (ARCTAS) mission: design, execution, and first results, Atmos. Chem. Phys., 10, 5191-5212, doi:10.5194/acp-10-5191-2010, 2010.

Klimont, Z., Smith, S. J., and Cofala, J.: The last decade of global anthropogenic sulfur dioxide: 2000-2011 emissions, Environ. Res. Lett., 8, 014003, doi:10.1088/1748-9326/8/1/014003, 2013.

Koo, J.-H., Wang, Y., Kurosu, T. P., Chance, K., Rozanov, A., Richter, A., Oltmans, S. J., Thompson, A. M., Hair, J. W., Fenn, M. A., Weinheimer, A. J., Ryerson, T. B., Solberg, S., Huey, L. G., Liao, J., Dibb, J. E., Neuman, J. A., Nowak, J. B., Pierce, R. B., Natarajan, M., and Al-Saadi, J.: Characteristics of tropospheric ozone depletion events in the Arctic spring: analysis of the ARCTAS, ARCPAC, and ARCIONS measurements and satellite BrO observations, Atmos. Chem. Phys., 12, 9909-9922, doi:10.5194/acp-12-9909-2012, 2012.

Lait, L. R., Newman, P. A., Schoeberl, M. R., McGee, T., Twigg, L., Browell, E. V., Fenn, M. A., Grant, W. B., Butler, C. F., Bevilacqua, R., Davies, J., DeBacker, H., Andersen, S. B., Kyrö, E., Kivi, E., von der Gathen, P., Claude, H., Benesova, A., Skrivankova, P., Dorokhov, V., Zaitcev, I., Braathen, G., Gil, M., Litynska, Z., Moore, D., and Gerding, M.: Non-coincident interinstrument comparisons of ozone measurements using quasiconservative coordinates, Atmos. Chem. Phys., 4, 2345-2352, doi:10.5194/acp-4-2345-2004, 2004

Law, K. S., Stohl, A., Quinn, P. K., Brock, C. A., Burkhart, J. F., Paris, J.-D., Ancellet, G., Singh, H. B., Roiger, A., Schlager, H., Dibb, J., Jacob, D. J., Arnold, S. R., Pelon, J., and Thomas, J. L.: Arctic Air Pollution: New Insights from POLARCAT-IPY, B. Am. Meteorol. Soc., 95, 1873-1895, doi:10.1175/BAMS-D-13$00017.1,2014$.

Lee, D. S., Fahey, D. W., Forster, P. M., Newton, P. J., Wit, R. C., Lim, L. L., Owen, B., and Sausen, R.: Aviation and global climate change in the 21st century, Atmos. Environ., 43, 35203537, doi:10.1016/j.atmosenv.2009.04.024, 2009.

Legrand, M., Preunkert, S., Jourdain, B., Gallée, H., Goutail, F., Weller, R., and Savarino, J.: Year-round record of surface ozone at coastal (Dumont d'Urville) and inland (Concordia) sites in East Antarctica, J. Geophys. Res.-Atmos., 114, D20306, doi:10.1029/2008JD011667, 2009.

Lin, M., Horowitz, L. W., Cooper, O. R., Tarasick, D., Conley, S., Iraci, L. T., Johnson, B., Leblanc, T., Petropavlovskikh, I., and Yates, E. L.: Revisiting the evidence of increasing springtime ozone mixing ratios in the free troposphere over western North America, Geophys. Res. Lett., 42, 8719-8728, doi:10.1002/2015GL065311, 2015.

Livesey, N. J., Filipiak, M. J., Froidevaux, L., Read, W. G., Lambert, A., Santee, M. L., Jiang, J. H., Pumphrey, H. C., Waters, J. W., Cofield, R. E., Cuddy, D. T., Daffer, W. H., Drouin, B. J., Fuller, R. A., Jarnot, R. F., Jiang, Y. B., Knosp, B. W., Li, Q. B., Perun, V. S., Schwartz, M. J., Snyder, W. V., Stek, P. C., Thurstans, R. P., Wagner, P. A., Avery, M., Browell, E. V., Cammas, J.P., Christensen, L. E., Diskin, G. S., Gao, R.-S., Jost, H.-J., Loewenstein, M., Lopez, J. D., Nedelec, P., Osterman, G. B., 
Sachse, G. W., and Webster, C. R.: Validation of Aura Microwave Limb Sounder $\mathrm{O}_{3}$ and $\mathrm{CO}$ observations in the upper troposphere and lower stratosphere, J. Geophys. Res.-Atmos., 113, D15S02, doi:10.1029/2007JD008805, 2008.

Marelle, L., Raut, J.-C., Thomas, J. L., Law, K. S., Quennehen, B., Ancellet, G., Pelon, J., Schwarzenboeck, A., and Fast, J. D.: Transport of anthropogenic and biomass burning aerosols from Europe to the Arctic during spring 2008, Atmos. Chem. Phys., 15, 3831-3850, doi:10.5194/acp-15-3831-2015, 2015.

Marenco, A., Thouret, V., Nédélec, P., Smit, H., Helten, M., Kley, D., Karcher, F., Simon, P., Law, K., Pyle, J., Poschmann, G., Von Wrede, R., Hume, C., and Cook, T.: Measurement of ozone and water vapor by Airbus in-service aircraft: The MOZAIC airborne program, an overview, J. Geophys. Res.-Atmos., 103, 25631-25642, doi:10.1029/98JD00977, 1998.

Mauzerall, D., Jacob, D., Fan, S. M., Bradshaw, J., Gregory, G., Sachse, G., and Blake, D.: Origin of tropospheric ozone at remote high northern latitudes in summer, J. Geophys. Res., 101, 41754188, 1996.

Mlawer, E. J., Taubman, S. J., Brown, P. D., Iacono, M. J., and Clough, S. A.: Radiative transfer for inhomogeneous atmospheres: RRTM, a validated correlated-k model for the longwave, J. Geophys. Res.-Atmos., 102, 16663-16682, doi:10.1029/97JD00237, 1997.

Monks, S. A., Arnold, S. R., Emmons, L. K., Law, K. S., Turquety, S., Duncan, B. N., Flemming, J., Huijnen, V., Tilmes, S., Langner, J., Mao, J., Long, Y., Thomas, J. L., Steenrod, S. D., Raut, J. C., Wilson, C., Chipperfield, M. P., Diskin, G. S., Weinheimer, A., Schlager, H., and Ancellet, G.: Multi-model study of chemical and physical controls on transport of anthropogenic and biomass burning pollution to the Arctic, Atmos. Chem. Phys., 15, 3575-3603, doi:10.5194/acp-15-3575-2015, 2015.

Morrison, H., Thompson, G., and Tatarskii, V.: Impact of Cloud Microphysics on the Development of Trailing Stratiform Precipitation in a Simulated Squall Line: Comparison of One- and Two-Moment Schemes, Mon. Weather Rev., 137, 991-1007, doi:10.1175/2008MWR2556.1, 2009.

Olson, J. R., Crawford, J. H., Brune, W., Mao, J., Ren, X., Fried, A., Anderson, B., Apel, E., Beaver, M., Blake, D., Chen, G., Crounse, J., Dibb, J., Diskin, G., Hall, S. R., Huey, L. G., Knapp, D., Richter, D., Riemer, D., Clair, J. St., Ullmann, K., Walega, J., Weibring, P., Weinheimer, A., Wennberg, P., and Wisthaler, A.: An analysis of fast photochemistry over high northern latitudes during spring and summer using in-situ observations from ARCTAS and TOPSE, Atmos. Chem. Phys., 12, 6799-6825, doi:10.5194/acp-12-6799-2012, 2012.

Papayannis, A., Ancellet, G., Pelon, J., and Megie, G.: Multiwavelength lidar for ozone measurements in the troposphere and the lower stratosphere, Appl. Opt., 29, 467-476, 1990.

Parrish, D. D., Law, K. S., Staehelin, J., Derwent, R., Cooper, O. R., Tanimoto, H., Volz-Thomas, A., Gilge, S., Scheel, H.-E., Steinbacher, M., and Chan, E.: Long-term changes in lower tropospheric baseline ozone concentrations at northern mid-latitudes, Atmos. Chem. Phys., 12, 11485-11504, doi:10.5194/acp-1211485-2012, 2012.

Ravetta, F., Ancellet, G., Kowol-Santen, J., Wilson, R., and Nedeljkovic, D.: Ozone, temperature and wind field measurements in a tropopause fold: comparison with a mesoscale model simulation, Mon. Weather Rev., 127, 2641-2653, 1999.
Richter, D. A., Browell, E. V., Butler, C. F., and Higdon, N. S.: Advanced airborne UV DIAL for stratospheric and troposheric ozone and aerosol measurements, in: Advances in Atmospheric Remote Sensing with Lidar, edited by: Ansmann, A., SpringerVerlag New York, 395-398, 1997.

Roiger, A., Schlager, H., Schäfler, A., Huntrieser, H., Scheibe, M., Aufmhoff, H., Cooper, O. R., Sodemann, H., Stohl, A., Burkhart, J., Lazzara, M., Schiller, C., Law, K. S., and Arnold, F.: Insitu observation of Asian pollution transported into the Arctic lowermost stratosphere, Atmos. Chem. Phys., 11, 10975-10994, doi:10.5194/acp-11-10975-2011, 2011.

Schlager, H., Konopka, P., Schulte, P., Schumann, U., Ziereis, H., Arnold, F., Klemm, M., Hagen, D. E., Whitefield, P. D., and Ovarlez, J.: In-situ observations of air traffic emission signatures in the North Atlantic flight corridor, J. Geophys. Res.-Atmos. 102, 10739-10750, doi:10.1029/96JD03748, 1997.

Shindell, D.: Local and remote contributions to Arctic warming, Geophys. Res. Lett., 34, L14704, doi:10.1029/2007GL030221, 2007.

Shindell, D. T., Faluvegi, G., Koch, D. M., Schmidt, G. A., Unger, N., and Bauer, S. E.: Improved Attribution of Climate Forcing to Emissions, Science, 326, 716-718, doi:10.1126/science.1174760, 2009.

Simpson, W. R., von Glasow, R., Riedel, K., Anderson, P., Ariya, P., Bottenheim, J., Burrows, J., Carpenter, L. J., Frieß, U., Goodsite, M. E., Heard, D., Hutterli, M., Jacobi, H.-W., Kaleschke, L., Neff, B., Plane, J., Platt, U., Richter, A., Roscoe, H., Sander, R., Shepson, P., Sodeau, J., Steffen, A., Wagner, T., and Wolff, E.: Halogens and their role in polar boundary-layer ozone depletion, Atmos. Chem. Phys., 7, 4375-4418, doi:10.5194/acp-74375-2007, 2007.

Singh, H., Anderson, B., Brune, W., Cai, C., Cohen, R., Crawford, J., Cubison, M., Czech, E., Emmons, L., Fuelberg, H., Huey, G., Jacob, D., Jimenez, J., Kaduwela, A., Kondo, Y., Mao, J., Olson, J., Sachse, G., Vay, S., Weinheimer, A., Wennberg, P., and Wisthaler, A.: Pollution influences on atmospheric composition and chemistry at high northern latitudes: Boreal and California forest fire emissions, Atmos. Environ., 44, 4553-4564, doi:10.1016/j.atmosenv.2010.08.026, 2010.

Stohl, A., Berg, T., Burkhart, J. F., Fjǽraa, A. M., Forster, C., Herber, A., Hov, Ø., Lunder, C., McMillan, W. W., Oltmans, S., Shiobara, M., Simpson, D., Solberg, S., Stebel, K., Ström, J., Tørseth, K., Treffeisen, R., Virkkunen, K., and Yttri, K. E.: Arctic smoke - record high air pollution levels in the European Arctic due to agricultural fires in Eastern Europe in spring 2006, Atmos. Chem. Phys., 7, 511-534, doi:10.5194/acp-7-511-2007, 2007.

Tarasick, D.: ECC ozonesonde data, Environment and Climate Change Canada, Downsview, ON, Canada, available at: ftp:// es-ee.tor.ec.gc.ca/pub/ftpdt/ARC-IONSData/summer/ICARTT/, 2008.

Tarasick, D. W., Jin, J. J., Fioletov, V. E., Liu, G., Thompson, A. M., Oltmans, S. J., Liu, J., Sioris, C. E., Liu, X., Cooper, O. R., Dann, T., and Thouret, V.: High-resolution tropospheric ozone fields for INTEX and ARCTAS from IONS ozonesondes, J. Geophys. Res.-Atmos., 115, D20301, doi:10.1029/2009JD012918, 2010.

Thomas, J. L., Raut, J.-C., Law, K. S., Marelle, L., Ancellet, G., Ravetta, F., Fast, J. D., Pfister, G., Emmons, L. K., Diskin, G. S., Weinheimer, A., Roiger, A., and Schlager, H.: Pollution transport from North America to Greenland during summer 2008, 
Atmos. Chem. Phys., 13, 3825-3848, doi:10.5194/acp-13-38252013, 2013.

van der Werf, G. R., Randerson, J. T., Giglio, L., Collatz, G. J., Mu, M., Kasibhatla, P. S., Morton, D. C., DeFries, R. S., Jin, Y., and van Leeuwen, T. T.: Global fire emissions and the contribution of deforestation, savanna, forest, agricultural, and peat fires (19972009), Atmos. Chem. Phys., 10, 11707-11735, doi:10.5194/acp10-11707-2010, 2010.

Walker, T. W., Jones, D. B. A., Parrington, M., Henze, D. K., Murray, L. T., Bottenheim, J. W., Anlauf, K., Worden, J. R., Bowman, K. W., Shim, C., Singh, K., Kopacz, M., Tarasick, D. W., Davies, J., von der Gathen, P., Thompson, A. M., and Carouge, C. C.: Impacts of midlatitude precursor emissions and local photochemistry on ozone abundances in the Arctic, J. Geophys. Res.Atmos., 117, D01305, doi:10.1029/2011JD016370, 2012.

Wang, Y., Ridley, B., Fried, A., Cantrell, C., Davis, D., Chen, G., Snow, J., Heikes, B., Talbot, R., Dibb, J., Flocke, F., Weinheimer, A., Blake, N., Blake, D., Shetter, R., Lefer, B., Atlas, E., Coffey, M., Walega, J., and Wert, B.: Springtime photochemistry at northern mid and high latitudes, J. Geophys. Res.-Atmos., 108, 8358, doi:10.1029/2002JD002227, 2003.

Weinheimer, A.: NASA DC-8 aircraft data, ozone in-situ measurements, NCAR, Boulder, CO, USA, available at: http://www-air.larc.nasa.gov/cgi-bin/ArcView/arctas\# WEINHEIMER.ANDREW/, 2008.
Weinheimer, A. J., Walega, J. G., Ridley, B. A., Gary, B. L., Blake, D. R., Blake, N. J., Rowland, F. S., Sachse, G. W., Anderson, B. E., and Collins, J. E.: Meridional distributions of $\mathrm{NO}_{x}, \mathrm{NO}_{y}$, and other species in the lower stratosphere and upper troposphere during AASE II, Geophys. Res. Lett., 21, 2583-2586, doi:10.1029/94GL01897, 1994.

Wespes, C., Emmons, L., Edwards, D. P., Hannigan, J., Hurtmans, D., Saunois, M., Coheur, P.-F., Clerbaux, C., Coffey, M. T., Batchelor, R. L., Lindenmaier, R., Strong, K., Weinheimer, A. J., Nowak, J. B., Ryerson, T. B., Crounse, J. D., and Wennberg, P. O.: Analysis of ozone and nitric acid in spring and summer Arctic pollution using aircraft, ground-based, satellite observations and MOZART-4 model: source attribution and partitioning, Atmos. Chem. Phys., 12, 237-259, doi:10.5194/acp-12-237-2012, 2012.

Zängl, G. and Hoinka, K. P.: The Tropopause in the Polar Regions, J. Climate, 14, 3117-3139, doi:10.1175/15200442(2001)014<3117:TTITPR>2.0.CO;2, 2001.

Zaveri, R. A. and Peters, L. K.: A new lumped structure photochemical mechanism for large-scale applications, J. Geophys. Res.Atmos., 104, 30387-30415, doi:10.1029/1999JD900876, 1999.

Zaveri, R. A., Easter, R. C., Fast, J. D., and Peters, L. K.: Model for Simulating Aerosol Interactions and Chemistry (MOSAIC), J. Geophys. Res.-Atmos., 113, D13204, doi:10.1029/2007JD008782, 2008. 